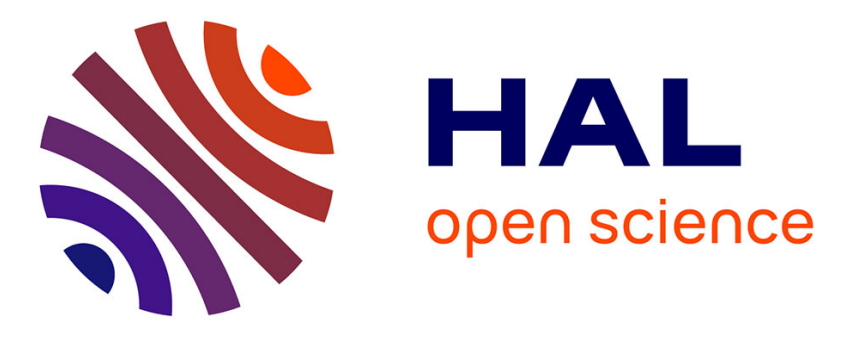

\title{
Giant scaffolding protein AHNAK1 interacts with $\beta$-dystroglycan and controls motility and mechanical properties of Schwann cells
}

Ysander von Boxberg, Sylvia Soares, Sophie Féréol, Redouane Fodil, Sylvain Bartolami, Jacques Taxi, Nicolas Tricaud, Fatiha Nothias

\section{To cite this version:}

Ysander von Boxberg, Sylvia Soares, Sophie Féréol, Redouane Fodil, Sylvain Bartolami, et al.. Giant scaffolding protein AHNAK1 interacts with $\beta$-dystroglycan and controls motility and mechanical properties of Schwann cells. Glia, 2014, 62 (9), pp.1392-1406. 10.1002/glia.22685 . hal-02156404

\author{
HAL Id: hal-02156404 \\ https://hal.science/hal-02156404
}

Submitted on 17 Jun 2019

HAL is a multi-disciplinary open access archive for the deposit and dissemination of scientific research documents, whether they are published or not. The documents may come from teaching and research institutions in France or abroad, or from public or private research centers.
L'archive ouverte pluridisciplinaire HAL, est destinée au dépôt et à la diffusion de documents scientifiques de niveau recherche, publiés ou non, émanant des établissements d'enseignement et de recherche français ou étrangers, des laboratoires publics ou privés. 


\title{
Giant Scaffolding Protein AHNAK1 Interacts with $\beta$-Dystroglycan and Controls Motility and Mechanical Properties of Schwann Cells
}

\author{
Ysander von Boxberg, ${ }^{1,2,3}$ Sylvia Soares, ${ }^{1,2,3}$ Sophie Féréol, ${ }^{4}$ Redouane Fodil, ${ }^{5}$ \\ Sylvain Bartolami, ${ }^{6}$ Jacques Taxi, ${ }^{1,2,3}$ Nicolas Tricaud, ${ }^{6}$ and Fatiha Nothias ${ }^{1,2,3}$
}

The profound morphofunctional changes that Schwann cells (SCs) undergo during their migration and elongation on axons, as well as during axon sorting, ensheathment, and myelination, require their close interaction with the surrounding lamininrich basal lamina. In contrast to myelinating central nervous system glia, SCs strongly and constitutively express the giant scaffolding protein AHNAK1, localized essentially underneath the outer, abaxonal plasma membrane. Using electron microscopy, we show here that in the sciatic nerve of ahnak $1^{-1-}$ mice the ultrastructure of myelinated, and unmyelinated (Remak) fibers is affected. The major SC laminin receptor $\beta$-dystroglycan co-immunoprecipitates with AHNAK1 shows reduced expression in ahnak $1^{-1-} \mathrm{SCs}$, and is no longer detectable in Cajal bands on myelinated fibers in ahnak $1^{-1-}$ sciatic nerve. Reduced migration velocity in a scratch wound assay of purified ahnak $1^{-1-}$ primary SCs cultured on a laminin substrate indicated a function of AHNAK1 in SC motility. This was corroborated by atomic force microscopy measurements, which revealed a greater mechanical rigidity of shaft and leading tip of ahnak $1^{-1-} \mathrm{SC}$ processes. Internodal lengths of large fibers are decreased in ahnak $1^{-1-}$ sciatic nerve, and longitudinal extension of myelin segments is even more strongly reduced after acute knockdown of AHNAK1 in SCs of developing sciatic nerve. Together, our results suggest that by interfering in the cross-talk between the transmembrane form of the laminin receptor dystroglycan and F-actin, AHNAK1 influences the cytoskeleton organization of SCs, and thus plays a role in the regulation of their morphology and motility and lastly, the myelination process.

Key words: myelin, remak fibers, dystroglycan, shRNA knockdown, atomic force microscopy

GLIA 2014;00:000-000

\section{Introduction}

Cince the pioneering work of Bunge and others (Bunge and Bunge, 1978; Cornbrooks et al., 1983) we know that intricate contact of SCs with laminin-containing basement membrane is a prerequisite for the myelination process in peripheral nervous system (PNS), in addition to signaling from axons. SCs are polarized, with an apical domain corresponding to their adaxonal membrane and the myelin loops, whose extension is finely controlled with regard to the axon diameter, while their abaxonal membrane (in contact with basal lamina) represents the basolateral domain (Ozcelik et al., 2010). Laminin, produced partly by the SCs themselves, is indeed essential for SC proliferation, morphogenesis, and the myelination process (McKee et al., 2012). Thus, congenital muscular dystrophy and many other hereditary peripheral neuropathies are caused by mutations in certain laminin isoforms, or their receptors on SCs (i.e., dystroglycan and integrins; Colognato et al., 2005; Helbling-Leclerc et al., 1995; Sunada et al., 1994). During development, SCs perform a radial sorting of fibers: groups of small caliber axons $(<1 \mu \mathrm{m})$ are enwrapped by SC membrane without myelin deposition (Remak fibers), larger axons are pushed out of the bundle and are myelinated. Fiber sorting is severely affected in mutant mice lacking laminin receptors dystroglycan, and/or $\beta$-integrins (Berti et al., 2011; Feltri and Wrabetz, 2005).

View this article online at wileyonlinelibrary.com. DOI: 10.1002/glia.22685

Published online Month 00, 2014 in Wiley Online Library (wileyonlinelibrary.com). Received Oct 10, 2013, Accepted for publication Apr 17, 2014.

Address correspondence to Ysander von Boxberg, CNRS UMR8246_INSERM U1130_Sorbonne Universités UPMC, F-75005 Paris, France. E-mail: yboxberg@ snv.jussieu.fr or Fatiha Nothias, CNRS UMR8246_INSERM U1130_Sorbonne Universités UPMC, F-75005 Paris, France. E-mail: fnothias@snv.jussieu.fr

From the ${ }^{1}$ Sorbonne Universités, UPMC CR18 (NPS), Paris, France; ${ }^{2}$ Neuroscience Paris Seine (NPS), CNRS UMR 8246, Paris, France; ${ }^{3}$ Neuroscience Paris Seine (NPS), INSERM U1130, Paris, France; ${ }^{4}$ Mondor Institute for Biomedical Research, INSERM U955, Créteil University, Créteil, Paris, France; ${ }^{5}$ Institut Supérieur de BioSciences de Paris (ISBS), Créteil University, Créteil, Paris, France; ${ }^{6}$ Institute of Neurosciences Montpellier, INSERM U1051-University of Montpellier-1 and-2, St. Eloi hospital, Montpellier, France. 
We previously reported the giant scaffold protein AHNAK1 $(700 \mathrm{kDa})$ to be constitutively expressed in SCs (Salim et al., 2009), while it is absent from CNS oligodendrocytes (von Boxberg et al., 2006). We had shown that siRNA knockdown of ahnak1 in cultured SCs induced morphological changes and detachment from the laminin substrate. AHNAK1 protein has a rather unusual tripartite structure (Shtivelman et al., 1992), the largest part of which is composed of repeat domains, flanked by a short PDZ domain-bearing $\mathrm{N}$-terminus, and a longer $\mathrm{C}$-terminal domain responsible for most of its functions known so far. Based on sequence homology revealed by BLAST experiments, and a similar gene structure (a giant exon flanked by one ore more small exons forming a continuous ORF, translated into a tripartite repeat protein; see de Morree et al., 2012), AHNAK1 can be grouped in a small protein family with AHNAK2, whose primary, secondary, and tertiary structures closely resemble those of AHNAK1 (Komuro et al., 2004), and periaxin, a protein involved in the organization of abaxonal SC domains (Court et al., 2004; Gillespie et al., 1994). AHNAK1 is widely expressed, particularly in cells enduring physical stress, such as endo- and epithelial cells, and muscle (Gentil et al., 2003). It is implicated in $\mathrm{Ca}^{2+}$ signaling by interfering with the annexin-2/S100A10 complex in epithelial cells (Benaud et al., 2004), and with the L-type $\mathrm{Ca}_{\mathrm{v}}$ channel in skeletal muscle and myocard (Haase et al., 2005; Pankonien et al., 2012), but also in cytolytic T cells (Matza et al., 2008, 2009). AHNAK1 is thought to interact with the actin cytoskeleton (Benaud et al., 2004; Haase et al., 2004), and its distribution is secondarily affected in certain muscular dystrophies (Huang et al., 2007, 2008; Marg et al., 2010; Zacharias et al., 2011). However, its precise function remains unclear, and mutant mice lacking AHNAK1 are perfectly viable (Komuro et al., 2004; Kouno et al., 2004).

Here, we demonstrate that AHNAK interacts with the transmembrane form of the laminin receptor dystroglycan on SCs, and influences their motility and mechanical properties in vitro, and the length of myelin segments in vivo.

\section{Materials and Methods}

\section{Animals}

Generation of ahnak1-1- mice has been previously described (Kouno et al., 2004). The mice used in this study were originally obtained from RIKEN BioResource Center (Experimental Animal Division; Tsukuba, Ibaraki, Japan), before transfer and further breeding in our own animal facilities. Ahnak1 $1^{-1-}$ mice of either sex were used for experiments, with wildtype littermate for comparison. Animal care and experimental procedures were in accordance with European Union Committee's directives (86/609/EEC). For preparation of teased fibers and dissection of tissues for immunohistochemistry or Western blotting, mice were deeply anesthetized with pentobarbi- tal, and intracardially perfused either with saline supplemented with heparin followed by fixative (4\% paraformaldehyde [PFA] in $0.1 \mathrm{M}$ phosphate buffer), or with saline alone (for biochemistry).

\section{Reagents and Antibodies}

We used monoclonal anti- $\beta$-actin (C4, Santa Cruz Biotechnology), polyclonal anti- $\beta$-dystroglycan (H-242, Santa Cruz), monoclonal anti- $\beta$-dystroglycan (NCL-b-DG, NovoCastra), anti-dystrophin (H4, generous gift of H. Hardin-Pouzet; Royuela et al., 2003), rabbit anti-paranodin/Caspr (L51, generous gift of L. Goutebroze), monoclonal anti-GFP (clone 3E6, Invitrogen), monoclonal anti-myelin basic protein (MBP, Chemicon), rabbit anti-AHNAK A5 (generated against a GST-fusion protein corresponding to clone A5 partial ahnak sequence from rat, GeneBank acc. no. DQ203292.1; von Boxberg et al., 2006), anti-AHNAK peptide antibodies KIS and CQL (kindly provided by J. Baudier; Gentil et al., 2003), and antip75 low affinity NGF receptor (AB1554, Millipore). Fluorescent secondary antibodies were Alexa-555 or -488 coupled, in some cases associated with Alexa488-phalloidin labeling (all Molecular Probes, Invitrogen).

\section{Immunohistochemistry}

Cells or nerves were (post-)fixed in 4\% PFA in 11\% sucrose in PBS for $30 \mathrm{~min}$, permeabilized in $0.3 \%$ Triton X-100 in PBS, and nonspecific binding sites blocked with 10\% normal goat serum (NGS) in PBS (or horse serum in case of goat-derived primary antibodies). After incubation with primary antibodies diluted in 5\% NGS/0.1\% Triton X-100 in PBS for $3 \mathrm{~h}$ at RT or overnight at $4{ }^{\circ} \mathrm{C}$, specimen were rinsed, incubated with appropriate fluorescent Alexa-555 or -488 coupled secondary antibodies, and mounted in Mowiol. For imaging, a Leica DMRB, or a Zeiss Axiovert 200 standard light microscope, or a Leica DMI 6000B laser scanning microscope was used.

For analysis of internodal lengths, sciatic nerves from 2 to 4 months old wildtype and ahnak1 ${ }^{-1-}$ mice (four mice per genotype) were teased on glass slides, postfixed in $2 \%$ PFA, and immunolabeled with antibodies against myelin basic protein (MBP, for measurement of total diameters of myelinated fibers), and Caspr/ paranodin (for detection of Ranvier nodes). Slides were scanned and photographed on a Zeiss AxioZoom-V16 macro-apotome microscope, and individual fiber diameters and corresponding internodal distances were measured manually using ImageJ (Fiji) software (already evaluated fibers remain marked by the software, avoiding multiple counting of same internodes).

\section{Electron Microscopy}

Mice were deeply anesthetized as above, and perfused first with phosphate buffer $(\mathrm{PB})$, then with "Webster" fixative (PB with $0.5 \%$ PFA and $2.5 \%$ glutaraldehyde). After dissection, about $2 \mathrm{~mm}$ long pieces of sciatic nerve were postfixed overnight in Webster buffer at $4^{\circ} \mathrm{C}$, washed, treated with $2.5 \%$ osmium for $2-3 \mathrm{~h}$, washed again in $\mathrm{PB}$, then in water, before being dehydrated in an ethanol series, and mounted in Epon resin. Ultrathin sections were cut on a Reichert Ultracut-S microtome (Leica), mounted on grids, treated with lead citrate/uranyl acetate, and analyzed in a Zeiss 912 Omega electron 
microscope. Fiber diameters in Remak bundles were manually measured on electron microscope photomicrographs of transverse sections of sciatic nerve from wildtype and ahnak1 ${ }^{-1-}$ mice $(>1,350$, and $>2,200$ fibers, respectively, evaluated from three different mice per genotype), and special care was taken to avoid multiple counting of the same fibers on overlapping images.

\section{SC Culture and Migration Assay}

SCs were prepared from sciatic and trigeminal nerves of 2-4 months old mice. Cultures on poly-L-lysine/laminin substrate in serum-free $\mathrm{N} 2$ medium supplemented with $2 \mu \mathrm{g} / \mathrm{ml}$ forskolin and $10 \mathrm{ng} / \mathrm{mL}$ heregulin- $\beta 1$, p75 antibody-based magnetic cell sorting (to get rid of fibroblast contamination), and scratch wound migration assays (using a $200 \mu \mathrm{l}$ pipette tip; Meintanis et al., 2001) were performed as described in Bouquet et al. (2007). Evaluation of migration velocity was done on six scratch assays per condition (two independent cultures, each composed of three individual lamellae for both wildtype, and ahnak1-1- SC). Cultures were photographed at different timepoints; re-colonization of the scratch was measured on photographic images taken of always the same area, and for statistical evaluation finally expressed as percentage of closure of the gap. Mean migration velocity was calculated assuming that the scratch was $1 \mathrm{~mm}$ wide.

\section{Electrophoresis and Western Blotting}

Sciatic nerve was cut into small pieces and homogenized in $0.32 \mathrm{M}$ sucrose/2 mM EDTA/1 mM EGTA/10 mM Tris-HCl pH 7.4, centrifuged at $1,000 \mathrm{~g}$ for $5 \mathrm{~min}$, and the supernatant centrifuged at $17,000 \mathrm{~g}$ for $1 \mathrm{~h}$ at $4^{\circ} \mathrm{C}$, before solubilizing the pellet of the last centrifugation step. SCs in culture dishes or flasks were washed with PBS, and directly solubilized in the appropriate buffer for one- or two-dimensional electrophoresis, performed on a micro-scale as described (Boxberg, 1988; Salim et al., 2009). To reveal the rather acidic isoelectric points of $\beta$-dystroglycan by non-equilibrium $\mathrm{pH}$ gradient electrophoresis (NEPHGE), carrier ampholyte ("Servalyt," Serva) concentration was $1 \% 3-10,1 \% 3-5,1 \% 4-6,2 \%$ 5-8. Relative expression levels of $\beta$-dystroglycan in wildtype versus ahnak1 $1^{-l-}$ cells were determined from six independent experiments.

\section{Co-immunoprecipitation}

After testing different buffer systems for efficient immunoprecipitation of SC protein extract with AHNAK antibodies (see also: Benaud et al., 2004), cells were finally homogenized on ice in calcium/zinc containing "NP-40 buffer" (10 mM sodium phosphate pH 7.2, $1 \%$ NP-40, $150 \mathrm{mM} \mathrm{NaCl}, 1 \mathrm{mM} \mathrm{CaCl}_{2}, 10 \mu \mathrm{M} \mathrm{ZnSO}_{4}$, plus protease inhibitor cocktail, Sigma), by passing the cell suspension about 20 times through a syringe equipped with a $26 \mathrm{G}$ needle; starting with a near confluent T25 flask, final volume was about 0.5 $\mathrm{ml}$. After centrifugation for $5 \mathrm{~min}$ at $10,000 \mathrm{~g}$, the supernatant was subjected to immunoprecipitation using $\sim 5 \mu \mathrm{g}$ of CQL- or KISanti-AHNAK antibody coupled to Protein-A Dynabeads (Dynal, Invitrogen) according to the manufacturer's recommendations, the reaction being performed first for $10 \mathrm{~min}$ at $\mathrm{RT}$, then $2 \mathrm{~h}$ at $4^{\circ} \mathrm{C}$. Alternatively, $5 \mu \mathrm{g}$ of polyclonal $\beta$-dystroglycan antibody (Santa Cruz) was used (a monoclonal antibody was then used for Western blot detection of immunoprecipitated $\beta$-dystroglycan). After exten- sive washing of beads in NP-40 buffer, bound proteins were finally eluted with $20 \mu \mathrm{l} 8.5 \mathrm{M}$ urea/0.5 M thiourea/1\% NP-40 solution (same as used for protein solubilization for two-dimensional electrophoresis).

\section{Atomic Force Microscopy Analysis of SC Processes}

SCs were seeded at medium density onto poly-L-lysine/laminincoated glass coverslips and cultured for $24 \mathrm{~h}$ under usual conditions, before individual cells (well separated from other SCs or contaminating fibroblasts) were subjected to measurement of local process height and rigidity, using an AFM bench (JPK NanoWizard ${ }^{\circledR}$, Berlin, Germany) combined with an inverted microscope (Zeiss Axiovert 200), equipped with a silicon nitride cantilever probe with a lowest spring constant of typically $0.03 \mathrm{~N} / \mathrm{m}$ ( $\mu$ Mash, Sofia, Bulgaria). During the AFM measurement procedure, care was taken to keep temperature $\left(37^{\circ} \mathrm{C}\right)$ and $\mathrm{pH}$ of the medium constant $(25 \mathrm{mM}$ HEPES buffer $\mathrm{pH} 7.3$ was added). Calculation of process height and Young's modulus elasticity values was performed as described, using laboratory-made software (Fereol et al., 2011). Mean values were finally determined from measurements of 9 wildtype and 10 ahnak1 $1^{-1-}$ cells.

\section{shRNA Knockdown of ahnak1 in Sciatic Nerve of Mice}

Five different ahnak1 shRNA constructs (derived from mouse cDNA sequence NM_175108) packaged in MISSION ${ }^{\circledR}$ lentiviral transduction particles (Sigma; clone IDs: TRCN0000104945-104949) were tested on cultured SCs for their efficiency to knock down ahnak. Magnetically purified SCs cultured on poly-L-lysine/laminin-coated six-well plates in medium containing $10 \%$ fetal calf serum plus heregulin/forskolin were infected overnight with the different viral particles at a ratio (MOI) of five virus particles per cell (no polybrene [hexadimethrine bromide] was added, in contrast to standard infection protocols), before completely changing the medium. Forty-eight hours after viral infection, the medium was changed again, and 1-2 $\mu \mathrm{g} / \mathrm{ml}$ puromycin added (higher doses were found to be toxic). Cells were allowed to grow for another $48 \mathrm{~h}$, and finally harvested for AHNAK1 expression analysis by Western blotting. Selected MISSION shRNA constructs TRCN0000104947 and -104948 (hereafter termed \#7 and \#8) cloned into the plKO1-CMV-turboGFP plasmid vector (Sigma) were amplified in E. coli $\mathrm{DH} 5 \alpha$, before preparation of high titer virus solutions by transfection of HEK293T cells, and injection of virus into surgically exposed sciatic nerve of postnatal days 3-4 Swiss mice (Janvier, France) under isoflurane anesthesia, as described previously (Ozcelik et al., 2010). Mice were killed 2 months later, and teased fibers prepared from injected sciatic nerves. For cell size measurements, at least two injected animals were used for each condition. Wounded or dying cells were not counted. The length and the diameter (mean value of 10-20 measurements along the cell) of GFP-positive cells were determined using ImageJ software.

\section{Statistical Analysis}

Results are shown as average, statistical differences were determined using the Student's $t$-test with GraphPadPrism software, and 

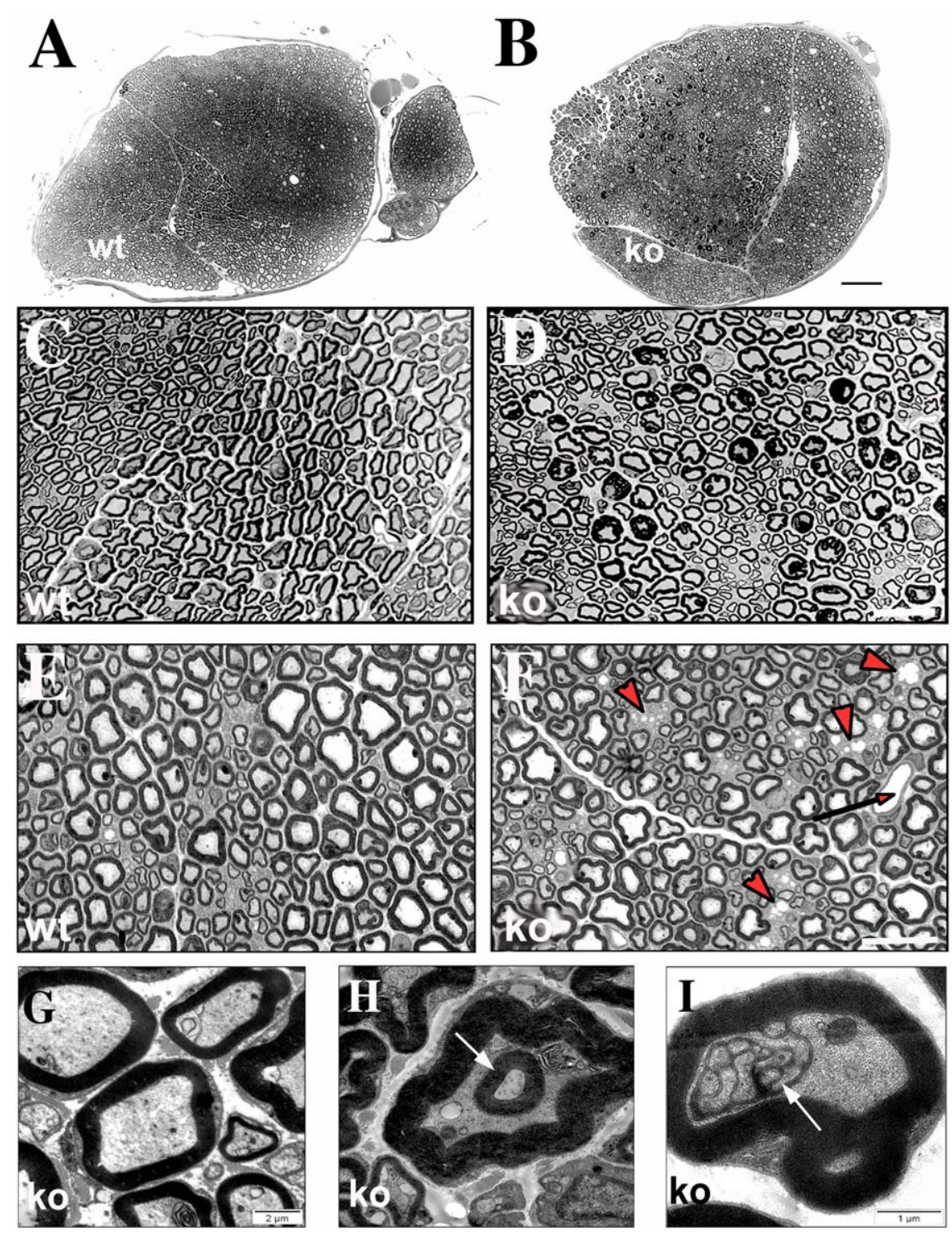

FIGURE 1: Aberrant myelin figures on semithin sections from 3 months old wildtype (left column: A, C, E), and ahnak1 ${ }^{-/-}$(right column: $B, D, F)$ mouse sciatic nerve. Although in ahnak $1^{-/-}$nerve the overall appearance of myelinated fibers is normal, a number of myelin thickenings/invaginations resembling tomaculae are observed (C, D are higher magnifications of $A, B$ ). Furthermore, in regions rich in non-myelinated Remak fibers, white "empty" spots (arrowheads in F; not seen in wildtype nerve, E) probably indicate the presence of unmyelinated large diameter, or blown-up fibers, not to be confused with blood vessels (small arrow in F). (G-I) Electron microscopic analysis shows that myelin figures in ahnak1 $1^{-1-}$ nerve are mostly normal (G), with occasional occurrence of invaginations ( $\mathrm{H}$, arrow), or the presence of multiple axons of different diameters in one myelin sheath (I, arrow). Bars, A, B, $100 \mu \mathrm{m} ; \mathrm{C}-\mathrm{F}, 10 \mu \mathrm{m}$. [Color figure can be viewed in the online issue, which is available at wileyonlinelibrary.com.]

considered significant with values $P<0.01 \quad(* *),<0.001 \quad(* *)$, $<0.0001{ }^{(* * *)}$, error bars represent SEM.

\section{Results}

\section{Lack of AHNAK1 Affects Fiber Sorting and Myelination in Sciatic Nerve}

We have previously shown that AHNAK1, although widely expressed in various tissues, is absent from central nervous system neurons, astroglia, and oligodendrocytes, while expressed in blood-brain barrier forming endothelial cells (von Boxberg et al., 2006). In contrast, it is found in small sized neurons and unmyelinated fibers in peripheral nervous system, and is strongly and constitutively expressed by both myelinating and non-myelinating SCs throughout life (Salim et al., 2009). This prompted us to investigate whether its absence from SCs would affect peripheral nerve organization/ ultrastructure. As seen on semithin sections of sciatic nerve (Fig. 1), myelination of ahnak1 $1^{-1-}$ nerve appeared normal at first sight, and g-ratios of myelinated fibers (ratio between axon and myelin sheath mean diameters) were not 

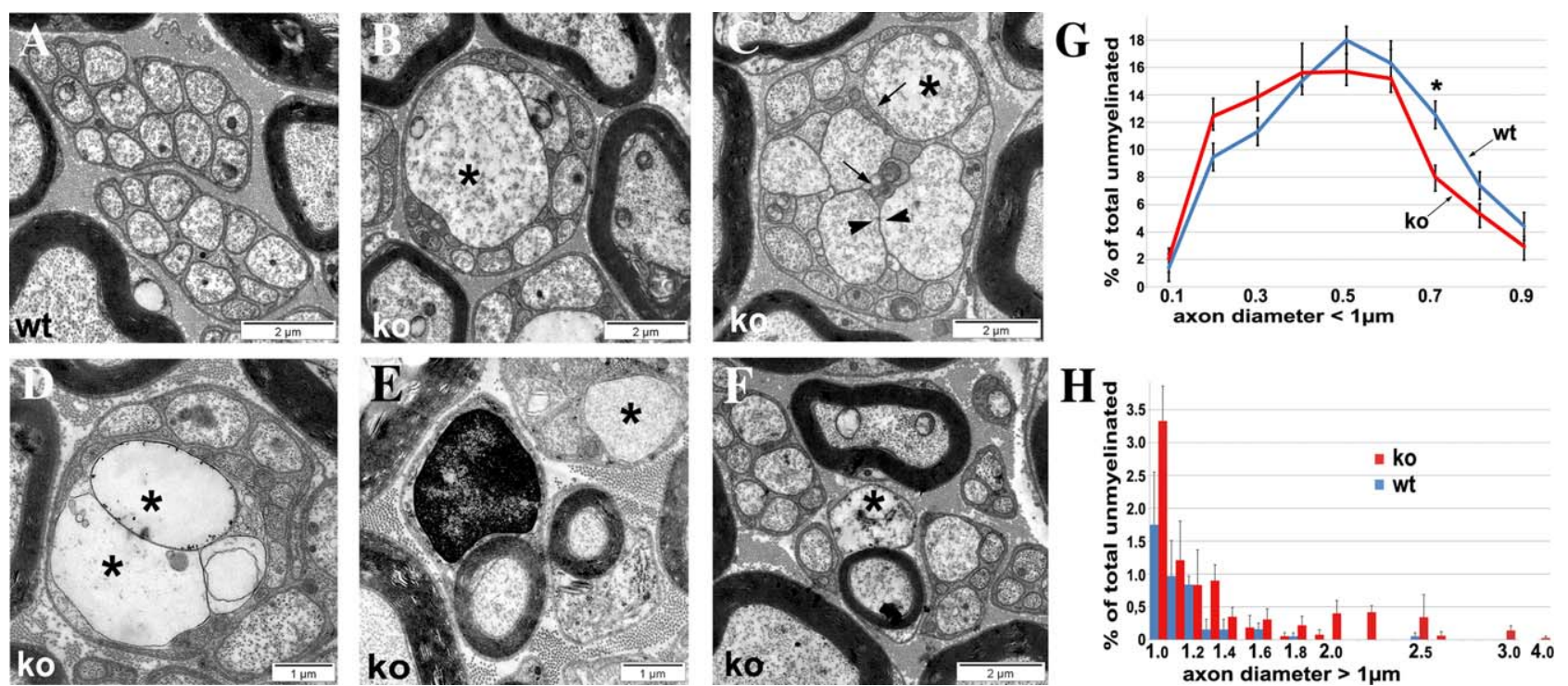

FIGURE 2: Electron microscopic analysis reveals defects of ahnak1-deficient unmyelinated Remak fibers. (A) Normal appearance of Remak bundles in wildtype sciatic nerve: most fibers exhibit a diameter around $0.5 \mu \mathrm{m}$, and are well separated by plasma membrane of nonmyelinating SCs. (B-F) Examples of unusually large diameter non-myelinated fibers (asterisks) in Remak bundles found within ahnak1 ${ }^{-/-}$ nerve, often non separated by SC membrane (arrowheads in C), sometimes appearing blown-up and almost devoid of cytoskeletal elements (D). Numerous instances of very small fibers are also observed (small arrow in C). Often, relatively large diameter non-myelinated axons are situated next to myelinated ones of rather smaller diameter (asterisks in $E$, $F$; the one in $F$ appears degenerating). Note that while these cases are frequent in ahnak1 $1^{-1-}$ nerve, many Remak fibers exhibit a rather normal appearance (see, e.g., Remak bundles in F). (G, H) Statistical evaluation of fiber diameters in Remak bundles from wildtype versus ahnak $1^{-1-}$ sciatic nerves. For each genotype, $>1,300$ Remak fibers were measured on electron microscopic images from sciatic nerve sections prepared from three different mice; with regard to the comparatively low absolute numbers of fibers larger than $1 \mu \mathrm{m}$, two graphs are presented for calibers below $1 \mu \mathrm{m}$ (G; average values with standard deviation, $\left.{ }^{*} P=0.028\right)$, and above $1 \mu \mathrm{m}(\mathrm{H}$; bar graph because of the low number, resp. absence of fibers for certain diameter values above $1.4 \mu \mathrm{m}$ ). [Color figure can be viewed in the online issue, which is available at wileyonlinelibrary.com.]

significantly different from wildtype values (not shown). Nevertheless, abnormally myelinated fibers were present in all ahnak1 $1^{-1-}$ sciatic nerves examined (e.g., thickenings resembling tomaculae, as seen, e.g., in Adlkofer et al., 1995; Goebbels et al., 2012; Fig. 1B,D). This was confirmed by electron microscopic analysis of ahnak1 ${ }^{-1-}$ sciatic nerve from different ages (6 weeks to 18 months), showing instances of myelin infoldings and penetration of myelin lamellae into the axon (cf., e.g., Lee et al., 2013), or myelination of multiple axons of different diameters by a single SC (Fig. 1H,I). A similar phenomenon has also been described for dystroglycan-null mice (Saito et al., 2003). However, the frequency of these myelin abnormalities exhibited a considerable variability between individual mice, and was thus not quantified.

Lack of AHNAK1 particularly affected small caliber, non-myelinated "Remak" fibers. Whereas in wildtype nerve, these fibers were generally well separated within the bundle, that is, individually enwrapped by cytoplasmic processes of a SC (Fig. 2A), Remak fiber ensheathment in ahnak1 ${ }^{-1-}$ mice was often either lacking, or incomplete (comparable for example to Remak fibers from Neuregulin-1 type III-deficient mice; Taveggia et al., 2005; see, e.g., Fig. 2C, arrowheads). Furthermore, while calibers of the vast majority of nonmyelinated fibers in wildtype nerve showed a roughly Gaus- sian distribution with a peak at around $0.5 \mu \mathrm{m}$, Remak fibers in ahnak1 $1^{-1-}$ nerve tended to be slightly thinner (see graph Fig. 2G; the difference was significant for $0.7 \mu \mathrm{m}$ fiber diameter, ${ }^{*} P=0.028$ ), and bundles also contained numerous very small fibers, or fiber debris (below $0.1 \mu \mathrm{m}$ diameter; Fig. 2C, small arrows). In contrast, Fig. 2 illustrates the presence in mutant nerve of numerous axons of calibers well above $1 \mu \mathrm{m}$ (up to $4 \mu \mathrm{m}$; asterisks) that should normally be myelinated, but instead were contained in a Remak bundle (see also the curious "empty" spots on semithin sections of ahnak1 ${ }^{-1-}$ nerve; arrowheads in Fig. 1F). Quantification of such abnormally large non-myelinated axons yielded an overall percentage of axons above or equal to $1.3 \mu \mathrm{m}$ diameter of about $4.7 \%$ for ahnakl $1^{-1-}$ versus only $0.7 \%$ for wildtype nerve (Fig. 2H; evaluation was performed on 2,250 axons for ahnak1 $1^{-1-}$, and 1,348 axons for wildtype nerve, from three mice per genotype). This phenomenon is suggestive of a defect in fiber sorting by SCs during development of the nerve. As an example, Fig. 2E shows a non-myelinated axon of $\sim 1.6 \mu \mathrm{m}$ diameter (asterisk) that obviously has not been "pushed out" of the bundle during development, while situated next to a myelinated fiber that is even smaller (another example of a fiber exhibiting more than $3.5 \mu \mathrm{m}$ next to a smaller myelinated axon is seen in Fig. 2B). 

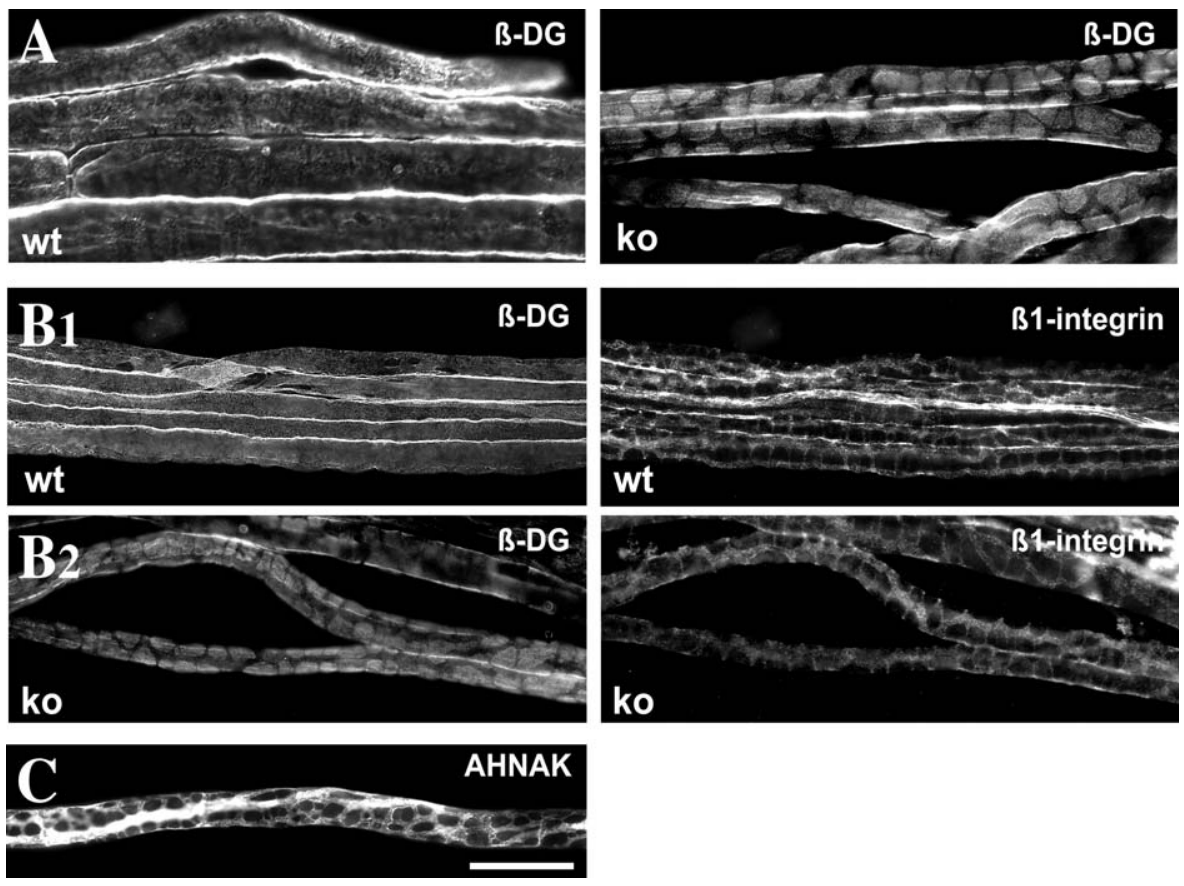

FIGURE 3: Altered distribution of $\beta$-dystroglycan on teased fibers from ahnak $1^{-/-}$nerve. (A) $\beta$-Dystroglycan is present throughout the abaxonal SC membrane on myelinated fibers in wildtype nerve (wt, left), but restricted to membrane appositions in ahnak $1^{-/-}$nerve, resembling the distribution of $\alpha$-dystroglycan (ko, right). (B) Bundles of teased fibers double stained for $\beta$-dystroglycan (left), and $\beta 1$-integrin (right), in wildtype (B1) and ahnak $1^{-/-}$nerve (B2). Note that lack of AHNAK1 does obviously not affect the distribution of $\beta 1$-integrin, another major laminin receptor of SC, present in Cajal bands. (C) Teased fiber from wildtype nerve stained for AHNAK1, localized exclusively in Cajal bands. Bar: A, C, $20 \mu \mathrm{m} ; \mathrm{B}, 30 \mu \mathrm{m}$.

\section{ahnak1 ${ }^{-/-}$Sciatic Nerve Fibers Exhibit Aberrant Distribution of $\beta$-Dystroglycan}

Axon sorting, ensheathing, and myelination by SCs being dependent on their close interaction with basal lamina, it seemed likely that the aforementioned defects may reflect an altered distribution of laminin receptors on the ahnak1 ${ }^{-1-}$ SC abaxonal membrane. Indeed, while staining of teased fibers revealed a more or less uniform distribution of $\beta$-dystroglycan in SC membranes of wildtype nerve (see also Court et al., 2011), $\beta$ dystroglycan was almost exclusively localized to membrane appositions in ahnak1 $1^{-1-}$ sciatic nerve (Fig. 3A,B2). Its distribution resembled that of the actual laminin-binding subunit $\alpha$ dystroglycan, absent from Cajal bands, and restricted to appositions of the abaxonal membrane to the outer myelin lamella (characterized by the presence of periaxin and Drp2; Court et al., 2011). In contrast, no difference between wildtype and ahnak1 ${ }^{-1-}$ nerve was observed in the distribution of another laminin receptor, $\beta 1$-integrin (Fig. 3B1,B2). This latter staining (as well as labeling for $\mathrm{S} 100$ protein, not shown) also suggests that the formation of Cajal bands is not affected in abnak1 ${ }^{-1-}$ nerve. Figure 3C shows the localization of AHNAK protein in Cajal bands of wildtype nerve (cf., Salim et al., 2009).

\section{AHNAK1 Interaction with $\beta$-Dystroglycan}

Figure 4A shows that $\beta$-dystroglycan expression in cultured purified ahnak1 $1^{-l-}$ SCs is reduced by about $35 \%$ compared with wildtype values (Fig. 4A1, arbitrary density values for wildtype and ahnak1 $1^{-1-}$ protein bands are $94.7 \pm 3.8 \mathrm{vs}$. $56.7 \pm 6.5 ; n=6, P<0.0001$ ), with a similar reduction being observed for sciatic nerve. This finding is consistent with the decreased presence of $\beta$-dystroglycan in Cajal bands within ahnak1 $1^{-1-}$ nerve (Fig. 3), and our previous report on the results of siRNA knockdown of ahnak1 in cultured SCs (Salim et al., 2009). The transmembrane laminin receptor $\beta$ dystroglycan is known to form a complex with submembranous dystrophin-116, the expression of which is also decreased in ahnak1 ${ }^{-1-}$ SCs (Fig. 4A, bottom). Furthermore, $\beta$-dystroglycan 43 co-immunoprecipitates with AHNAK1 from a protein extract of purified primary SC using protein Acoupled AHNAK1 antibodies ("CQL," anti-AHNAK-Cter peptide antibody used in Fig. 4B, as well as "KIS" anti-repeat domain peptide antibody, not shown), and AHNAK1 is also co-immunoprecipitated from wildtype SC protein extract using $\beta$-dystroglycan antibodies (Fig. 4B).

A cross-talk between $\beta$-dystroglycan and AHNAK1 is further suggested by two-dimensional electrophoresis of protein extracts from cultured purified wildtype and ahnak1 $1^{-1-}$ SCs, revealing a shift of the isoelectric point of $\beta$-dystrogly$\mathrm{can}_{43}$ to slightly more acidic values in cells lacking AHNAK1 (Fig. 4C). This may indicate a higher degree of phosphorylation, which is interesting as cSrc phosphorylation of $\mathrm{Tyr}^{892}$ is 
von Boxberg et al.: AHNAK1 Function in Schwann Cell Motility
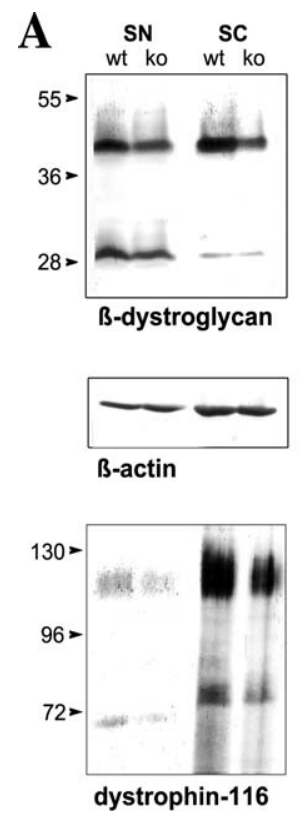
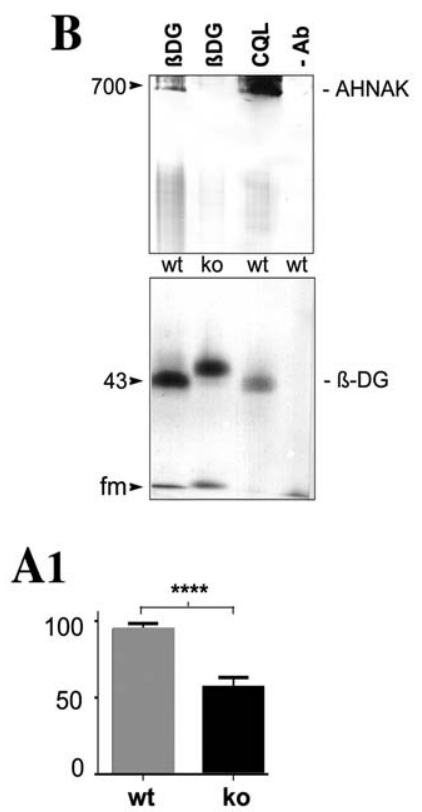

C
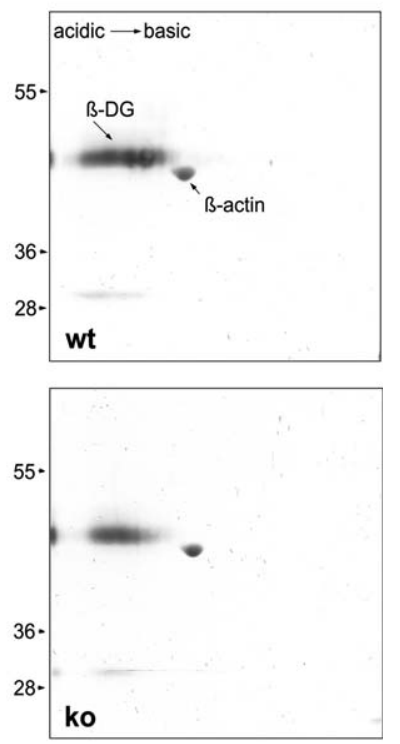

FIGURE 4: Link between $\beta$-dystroglycan and AHNAK1. (A) Western blots showing levels of $\beta$-dystroglycan (top panel), and dystrophin116 (bottom) to be higher in protein extracts from wildtype (wt) than from ahnak $1^{-1-}$ (ko) mice, both in sciatic nerve (SN), and in cultured primary Schwann cells (SC); $\beta$-actin staining is shown for reference, molecular weights of marker proteins are indicated to the left. Also note that $\beta$-dystroglycan ${ }_{30}$ is present in sciatic nerve, but hardly detected in purified SC. A quantitative evaluation of $\beta$ dystroglycan levels in protein extracts from cultured purified wildtype versus ahnak $1^{-1-}$ SC in shown in (A1). (B) Co-immunoprecipitation of $\beta$-dystroglycan ${ }_{43}$ and AHNAK1 from protein extracts of cultured primary SC. Protein-A-bound antibodies used are indicated on top: $\beta D G$, anti- $\beta$-dystroglycan; CQL, anti-AHNAK1 C-ter; -Ab, without antibody. Using $\beta$-dystroglycan antibodies the antigen can be immunoprecipitated from extracts of both wildtype and mutant SC, but AHNAK1 co-immunoprecipitates only when using wildtype SC extract. Inversely, $\beta$-dystroglycan co-immunoprecipitates with AHNAK1 when using CQL anti-AHNAK1 antibodies. Note that despite the enormous difference in molecular weights, AHNAK1 and $\beta$-dystroglycan bands were revealed on a Western blot prepared from the same gel; we ignore why the band of immunoprecipitated $\beta$-dystroglycan from mutant SC extract migrated slightly slower than that of wildtype (fm: front of migration). (C) Two-dimensional Western blot of protein extracts from purified wildtype and ahnak $1^{-1-} \mathrm{SCs}$, reacted with $\beta$-dystroglycan and $\beta$-actin antibodies. Compared with wildtype protein, the row of $\beta$-dystroglycan spots in ahnak $1^{-1-}$ cells is shifted to more acidic $\mathrm{pH}$ values (greater distance from the $\beta$-actin spot).

known to affect $\beta$-dystroglycan binding to dystrophin/utrophin, and to induce a redistribution of the protein from the plasma membrane to internal membranes, such as recycling endosomes (James et al., 2000; Sotgia et al., 2003). This interpretation is in accordance with our observation that in cultured SCs $\beta$-dystroglycan colocalizes with AHNAK1, and disappears from the plasma membrane when the cells reach confluency and thereby loose substrate contact, concomitant with a redistribution of AHNAK1 to the cytosol (Salim et al., 2009). Our data thus demonstrate that the submembranous scaffold protein AHNAK1 and transmembrane $\beta$ dystroglycan do indeed interact in cultured primary SCs, suggesting a similar interaction to occur also in peripheral nerve in vivo.

\section{Actin Cytoskeleton Organization and Motility of ahnak $1^{-/-}$SCs In Vitro}

Several studies provided evidence for interaction of AHNAK1 with the actin cytoskeleton (Benaud et al., 2004; Haase et al., 2004; Shankar et al., 2010). In SC processes and notably, in their tips resembling neuronal growth cones (see Bouquet et al., 2007), phalloidin labeling of F-actin revealed characteristic differences between wildtype and ahnak1 ${ }^{-1-}$ cells (Fig. 5A): wildtype process tips usually displayed a rounded, "exploring" growth cone-like shape with actin filaments splayed in multiple directions across the lamellipodium. In ahnak1 $1^{-1-}$ SC tips, actin filament organization was rather rectilinear, and many process tips appeared thinner, lancetlike. The likely effect of AHNAK1 deficiency on the interplay between cell surface laminin receptors and actin cytoskeleton then prompted us to assess the motility of abnak1 ${ }^{-1-}$ SCs using a scratch wound assay (Bouquet et al., 2007; Meintanis et al., 2001): on a confluent culture of cells plated on poly-Llysine/laminin in defined serum-free medium a cell-free stripe of about $1 \mathrm{~mm}$ is created, into which the cells then start to migrate from the border of the wound. As shown previously by Meintanis et al. (2001) and Bouquet et al. (2007), cell proliferation does not significantly contribute to reduction of the gap under these conditions. Cell migration was monitored over a $40 \mathrm{~h}$ period, after which wildtype SC had almost 


\section{GLLA}
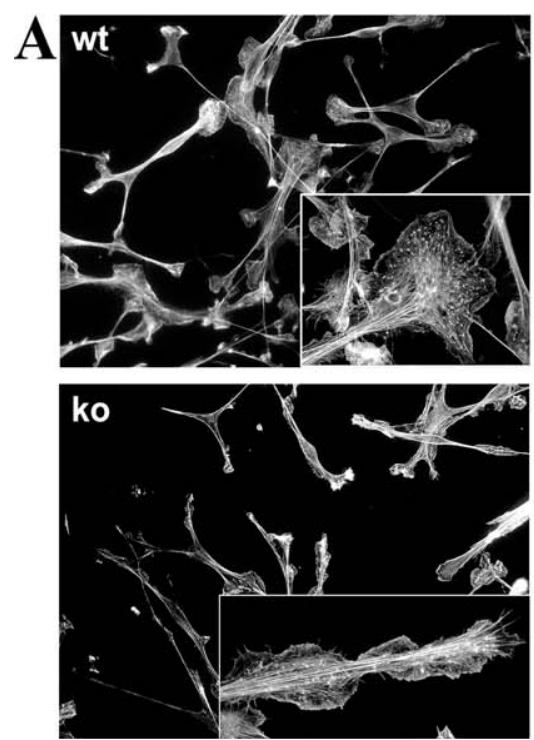
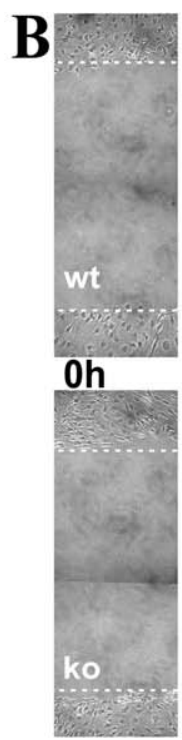

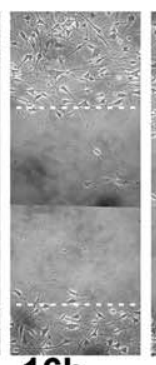

$16 \mathrm{~h}$

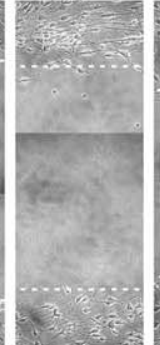

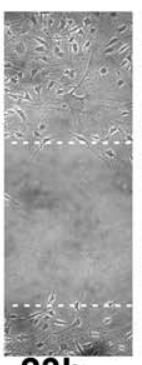

$23 \mathrm{~h}$

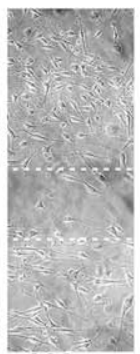

$40 \mathrm{~h}$

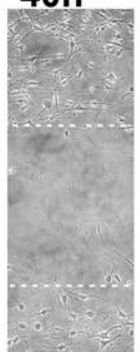

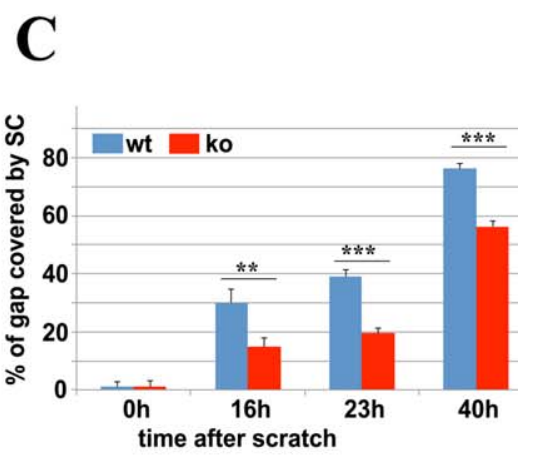

time after scratch

FIGURE 5: Altered actin cytoskeleton, and reduced motility of ahnak1 $1^{-1-}$ SCs. (A) Typical examples of processes and process tips from wildtype (wt) and ahnak1-ko (ko) SCs cultured for $24 \mathrm{~h}$; phalloidin labeling of F-actin, insets are higher magnifications of individual process tips. Note that in wildtype tips, resembling resting neural growth cones, actin filaments are oriented in all directions, whereas in the narrower, often lancet-like ahnak1 $1^{-1-}$ growth cones they appear bundled, and mainly oriented in the supposed direction of growth. (B) Example of a scratch wound assay performed on a confluent culture of purified primary SCs, top row wildtype (wt), bottom row ahnak $1^{-l-}$ (ko) cells, monitored over $40 \mathrm{~h}$; the front of migrating cells is indicated by broken white lines. (C) Comparison of migration velocities (corresponding to relative closure of the gap with time) of wildtype and ahnak1-1- SCs; for each condition, evaluation of six lamellae (migration assays) with cells from two independent experiments, error bars represent SEM. [Color figure can be viewed in the online issue, which is available at wileyonlinelibrary.com.]

completely re-colonized the gap. Mean velocity of cell migration into the gap over the first $23 \mathrm{~h}$ was $16.9 \mu \mathrm{m} / \mathrm{h}$ for wildtype, versus $8.6 \mu \mathrm{m} / \mathrm{h}$ for abnak1 $1^{-1-}$ cells (Fig. 5B,C). Thus, migration velocity of ahnak1 $1^{-1-}$ SCs was reduced by about $50 \%$ in comparison to wildtype cells.

\section{Stiffness of SC Processes Increased by Lack of AHNAK1}

The reduced motility of ahnak1 ${ }^{-1-}$ SCs and the modified morphology and actin-filament organization of their process end tips prompted us to evaluate the rigidity of these cells. We thus used atomic force microscopy (AFM) to compare tension forces in wildtype and ahnak1 ${ }^{-/-}$SC processes extending on a homogeneous laminin substrate. Indeed, internal tension and organization of the cytoskeleton can be related to the local rigidity of the cell or its processes (Canadas et al., 2002; Laurent et al., 2002; Wang et al., 2002; Wendling et al., 1999), which we assessed here as detailed previously (Fereol et al., 2009, 2011). Figure 6 summarizes our data obtained from measurements of 9 wildtype (283 individual points), and 10 ahnakl $1^{-1-}$ (330 individual points) SC processes. Thus, excepting their distal tip, wildtype processes display rather low rigidity along their shaft, as indicated by a mean Young's modulus of about $5 \mathrm{kPa}(5.42 \pm 0.025$ $\mathrm{kPa})$. At the growth cone-like tip, stiffness rises to a mean Young's modulus value of about $13 \mathrm{kPa}(13.05 \pm 1.43 \mathrm{kPa}$; locally up to $30 \mathrm{kPa}$ ). Both these values are significantly higher for processes of ahnak1 ${ }^{-1-}$ SCs: mean Young's modulus values are about $7 \mathrm{kPa}$ for the process shaft $(6.97 \pm 0.41$ $\mathrm{kPa})$, and about $19 \mathrm{kPa}(18.99 \pm 1.28 \mathrm{kPa})$ for the growth cone-like tip $(+22 \%$, and $+31 \%$, respectively, compared with wildtype values; $P<0.01)$. Moreover, process height $(z$ axis measure of the distance between top of process and substrate) is also significantly different between wildtype and ahnak1 $1^{-1-}$ SCs, notably at end tips: the height of ahnak1 $1^{-1-}$ process tips is increased by roughly $43 \%$ compared with values of wildtype cells $\left(1.13 \pm 0.036 \mu \mathrm{m}\right.$ for ahnak1 ${ }^{-1-}$ SC $v$ s. $0.64 \pm 0.087 \mu \mathrm{m}$ for wildtype SC; $P<0.0001)$. Even proximal parts of ahnak1 ${ }^{-1-}$ SC processes are about $16 \%$ higher than their wildtype counterparts $(1.13 \pm 0.048 \mu \mathrm{m}$ for wildtype, vs. $1.35 \pm 0.042 \mu \mathrm{m}$ for ahnak1 ${ }^{-1-}$ processes). These differences are likely reflected in the shapes, and the respective actin cytoskeleton organization of typical wildtype and ahnak1 $1^{-l-}$ SC end tips (Fig. 5A). Finally, for ahnak1 $1^{-1-}$ $\mathrm{SCs}$, rigidity values along the shaft appear to vary considerably, whereas they are almost constant for wildtype processes.

\section{Does lack of AHNAK1 in SCs Affect Internodal Length?}

The altered actin cytoskeleton, higher than normal stiffness, lower substrate adhesion, and reduced migration velocity of ahnak1 ${ }^{-1-}$ SCs, as well as the abnormal $\beta$-dystroglycan distribution in myelinated fibers of ahnak1 ${ }^{-1-}$ mouse sciatic nerve suggested to us that lack of AHNAK1 might affect the 

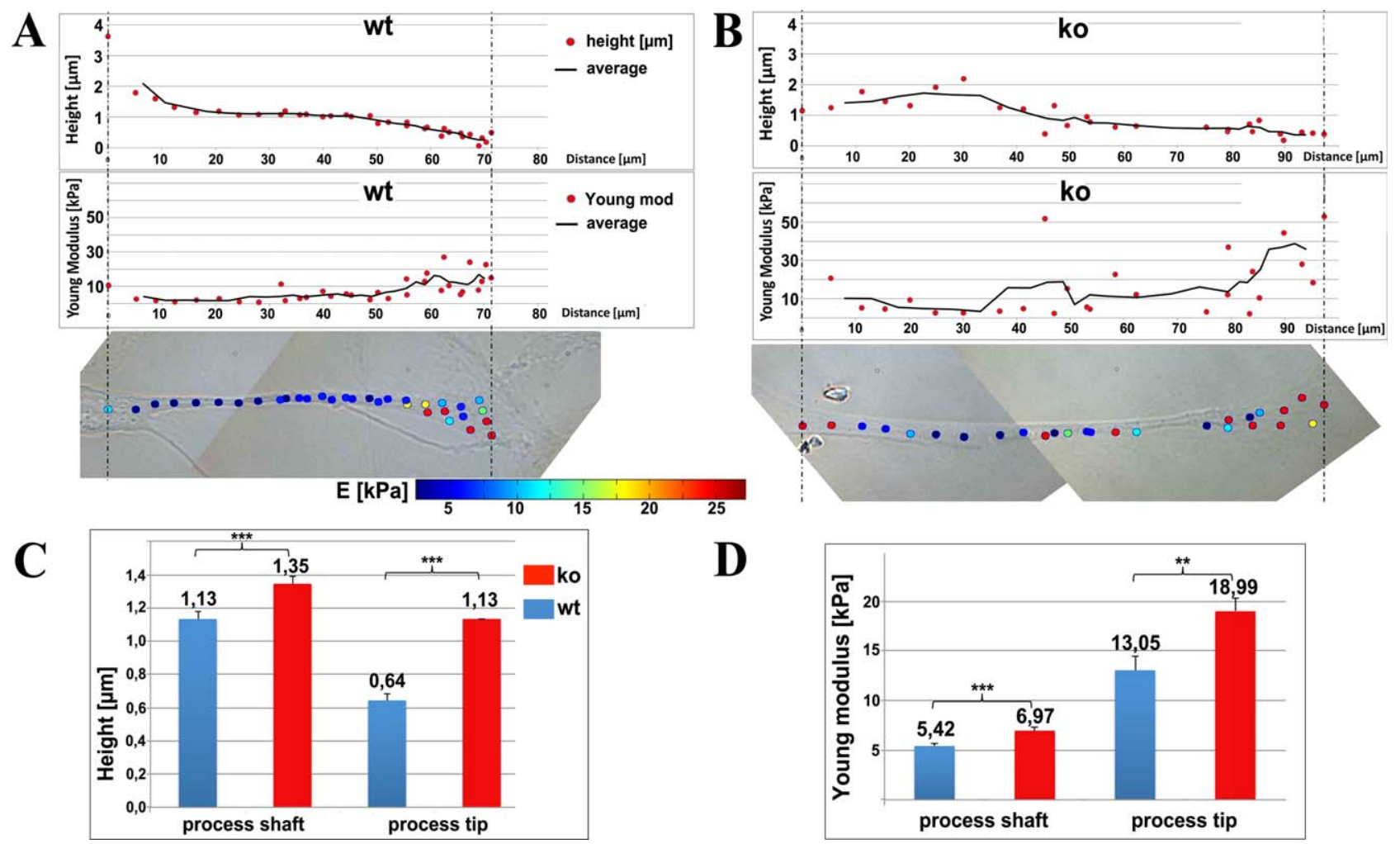

D

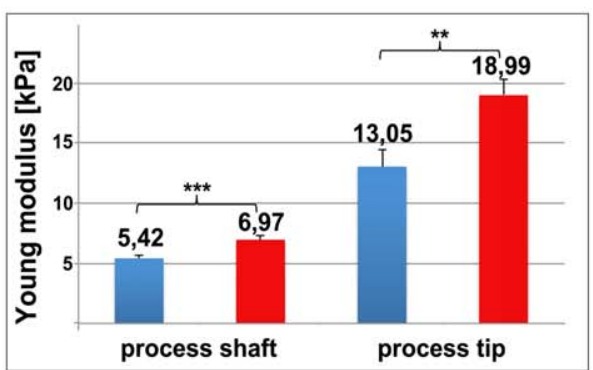

FIGURE 6: Mechanical properties of SC processes affected by lack of AHNAK. (A, B) Local height (z-axis measures; top panels), and local rigidity (Young's modulus values, middle panels), with corresponding points of measurement along the process (phase contrast images, bottom panels); representative curves are shown for (A) wildtype (wt), (B) ahnak $1^{-1-}$ (ko) cells. ahnak $1^{-1-}$ processes display an overall greater height, and higher rigidity, particularly at the leading tip, and elasticity varies considerably along the shaft. (C, D) Statistical evaluation of height (C), and Young's modulus values (D) of process shafts and growth cones from wildtype (wt, $n=9$ ) and ahnak1-ko (ko, $n=10)$ SCs; error bars represent SEM. Mean height, and mean rigidity of ahnak $1^{-1}$ process tips exceed wildtype values by roughly $43 \%$, and $31 \%$, respectively. [Color figure can be viewed in the online issue, which is available at wileyonlinelibrary.com.]

elongation process of myelinating SC on peripheral axons. We therefore compared internodal lengths of teased fibers of sciatic nerve prepared from 2 to 4 months old (mature) wildtype and ahnak1 $1^{-1-}$ mice $(n=4$ per genotype). The scatter graph (Fig. 7A) representing internodal lengths of individual fibers in relation to their diameter shows that for a given fiber diameter, mean internodal lengths were indeed higher in

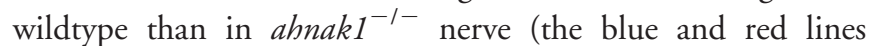
indicate mean values for wildtype, and ahnak1 ${ }^{-1-}$ fibers, respectively). As illustrated in Fig. $7 \mathrm{~B}$, internodal length differences are significant only for larger fibers, similar to results reported by Court et al. (2009) for mice lacking dystroglycan, dystrophin, or utrophin. For fiber calibers between 10 and 15 $\mu \mathrm{m}$, the reduction in mean internodal length in ahnak1 $1^{-1-}$ nerve is about $10 \%$, lower than that observed in dystroglycan-ko mice, but comparable to dystrophin-ko mice.

\section{shRNA Knockdown of ahnak1 In Vivo Results in Drastic Shortening of Internodes}

As lack of AHNAK appeared to only mildly affect internodal length and peripheral nerve ultrastructure, in contrast to what may have been expected from its more pronounced effects on purified cultured SCs, we decided to perform an acute knockdown of ahnak in sciatic nerve of live mice, as described in Ozcelik et al. (2010) and Cotter et al. (2010). To select appropriate shRNA constructs for efficient knockdown, we first infected cultured purified SCs (and MDCK cells, an endothelial cell line expressing high amounts of AHNAK; not shown) with lentiviral vectors harboring different shRNA constructs (MISSION ${ }^{\circledR}$, Sigma). After puromycin selection, infected cells were harvested and AHNAK1 levels assessed by Western blotting. Two shRNA constructs found to efficiently knock down AHNAK1 in cultured SCs (\#7 and \#8, Fig. 8A) were then subcloned into a cassette containing a turbo-GFP sequence for easy tracing of infected cells, and inserted into pSICOR lentiviral plasmids. High titer virus solutions were produced and injected into sciatic nerves of 3-4 days old mouse pups, when peripheral myelination is starting. In these conditions, lentivirus have been shown to infect mostly myelinating Schwann cells (see Cotter et al., 2010; Ozcelik et al., 2010). Mice were sacrificed 2 months later when myelination is accomplished, and teased fibers from sciatic nerve prepared to examine the morphology of AHNAK1-silenced SCs using confocal microscopy (an example of a GFP expressing 

(2)
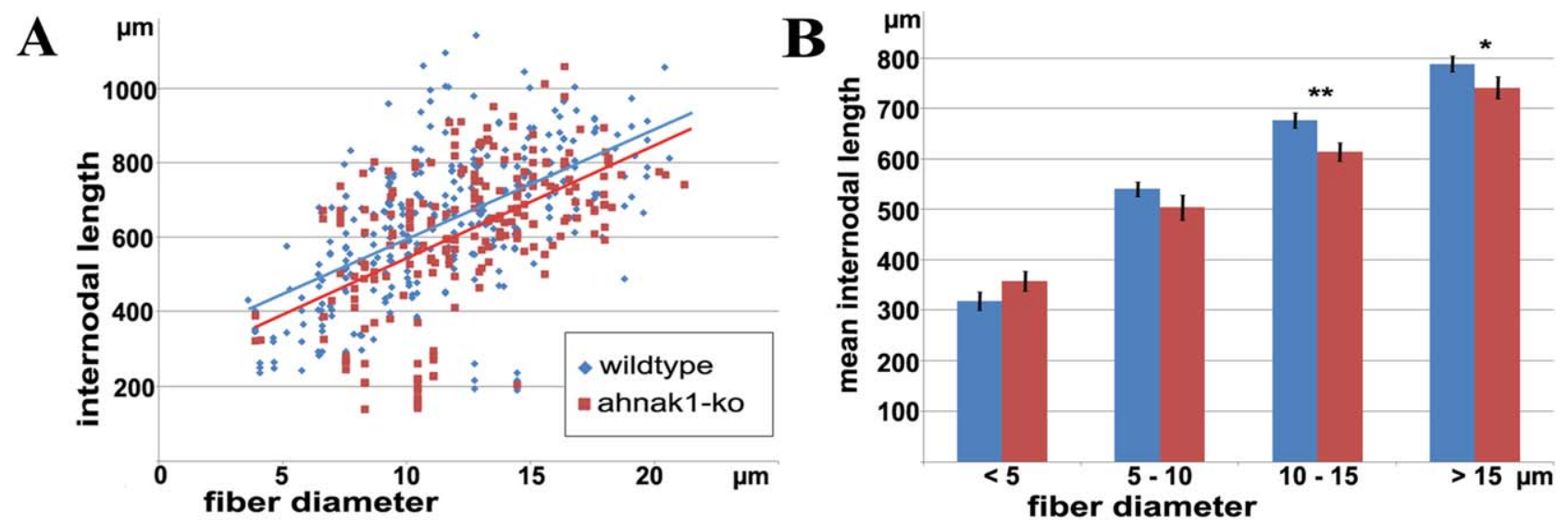

\section{C}

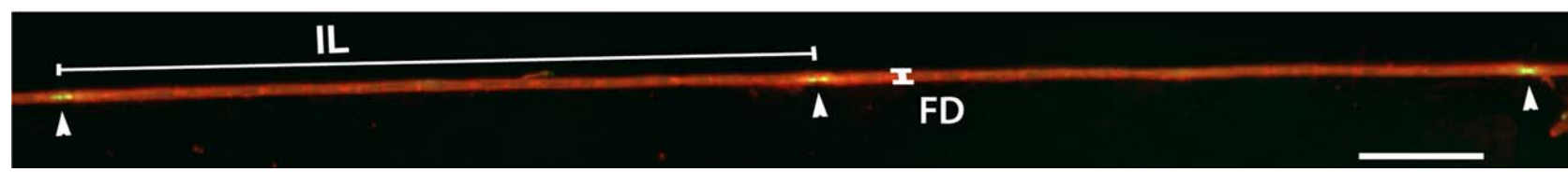

FIGURE 7: Comparison of internodal lengths (IL) in wildtype and ahnak1 $1^{-1-}$ sciatic nerve. (A) Scatter graph showing individual IL in relation to corresponding fiber diameters, evaluation of 313 wildtype (blue) and 221 ahnak $1^{-/-}$fibers (red). The blue and red lines indicate average IL values for a given fiber caliber. (B) Mean IL values for fibers grouped into categories of less than 5, 5-10, 10-15, and over 15 $\mu \mathrm{m}$ diameter. For large fibers (above $10 \mu \mathrm{m}$ ) the IL are significantly different between wildtype and ahnak $1^{-1-}$ nerves $\left({ }^{*} P=0.035 ; * *\right.$ $P=0.009$; Student's t-test). (C) Example of a teased fiber double stained for MBP (red) and Caspr/paranodin (green); IL: internodal length, FD: myelinated fiber diameter, arrowheads mark Ranvier nodes. Bar, $100 \mu \mathrm{m}$. [Color figure can be viewed in the online issue, which is available at wileyonlinelibrary.com.]

AHNAK1-silenced vs. a control, non-target shRNA-infected SC is shown in Fig. 8B1; Fig. 8B2 illustrates efficient silencing of AHNAK1 in \#sh8-infected SCs). We found that cells expressing AHNAK1 shRNA \#8 were dramatically shorter and thinner than control cells expressing a non-targeted shRNA (Fig. 8C,D): mean length of control cells was $332.0 \pm 16.2 \mu \mathrm{m}$, that of AHNAK1-silenced cells $82.5 \pm 4.3$ $\mu \mathrm{m} ; \quad P<0.0001$; mean diameter of control cells was $6.7 \pm 0.3 \mu \mathrm{m}$, compared with $3.8 \pm 0.1 \mu \mathrm{m}$ for AHNAK1silenced cells; $P<0.0001$. Similar results were obtained after infection with the lentiviral construct harboring AHNAK1 shRNA \#7 (not shown), suggesting that the observed effect on internodal length is not due to off target silencing. In the absence of compensatory mechanisms likely to be active in ahnak1-deficient nerve during embryonic development (see Discussion), acute knockdown of ahnak1 in SCs at the onset of myelination thus leads to an important decrease in the elongation of SCs on the axons.

\section{Discussion}

This data show that axon sorting and ensheathing are affected in peripheral nerve of ahnak1 $1^{-1-}$ mice. Moreover, acute ahnak1-shRNA knockdown targeted to SCs results in strikingly shorter internodes. In vitro, the lower motility, and higher mechanical rigidity of ahnak1 ${ }^{-1-}$ SCs indicate a per- turbed interaction with the laminin substrate. Together, our results suggest that AHNAK1, through interaction with the dystroglycan/dystrophin/utrophin complex, is involved in actin cytoskeleton regulation in reaction to binding of the SC plasma membrane to laminin.

The differences between myelinating glial cells of PNS and CNS are manifold, and AHNAK1 constitutes an additional molecular marker differentiating SCs from oligodendrocytes. Thus, in addition to myelination and ensheathing, SCs are capable of phagocytosis of myelin debris, controlling inflammation, and production of trophic factors in response to injury; in contrast to oligodendrocytes, myelinating SCs exhibit a strict one-to-one relationship with axons; SchmidtLanterman incisures and paranodal microvilli are unique to peripheral myelin, whose molecular composition is also partially different (for review: Sherman and Brophy, 2005). Here, with regard to the potential role of AHNAK1 in SCs, we focus on their requirement to closely interact with the laminin-rich basal lamina surrounding their outer (abaxonal) plasma membrane. After myelination, this abaxonal membrane envelops the residual SC cytoplasm, organized in "Cajal bands" separated by patches of membrane directly apposed to the myelin sheath (another striking difference with oligodendroglia; Court et al., 2004). No basement membrane is present around myelinated fibers in CNS, although laminin 

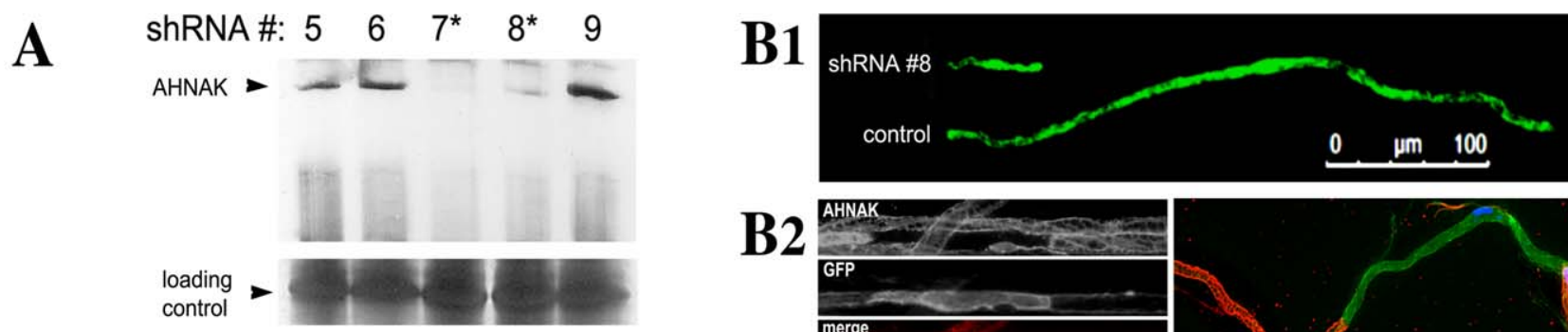

B2
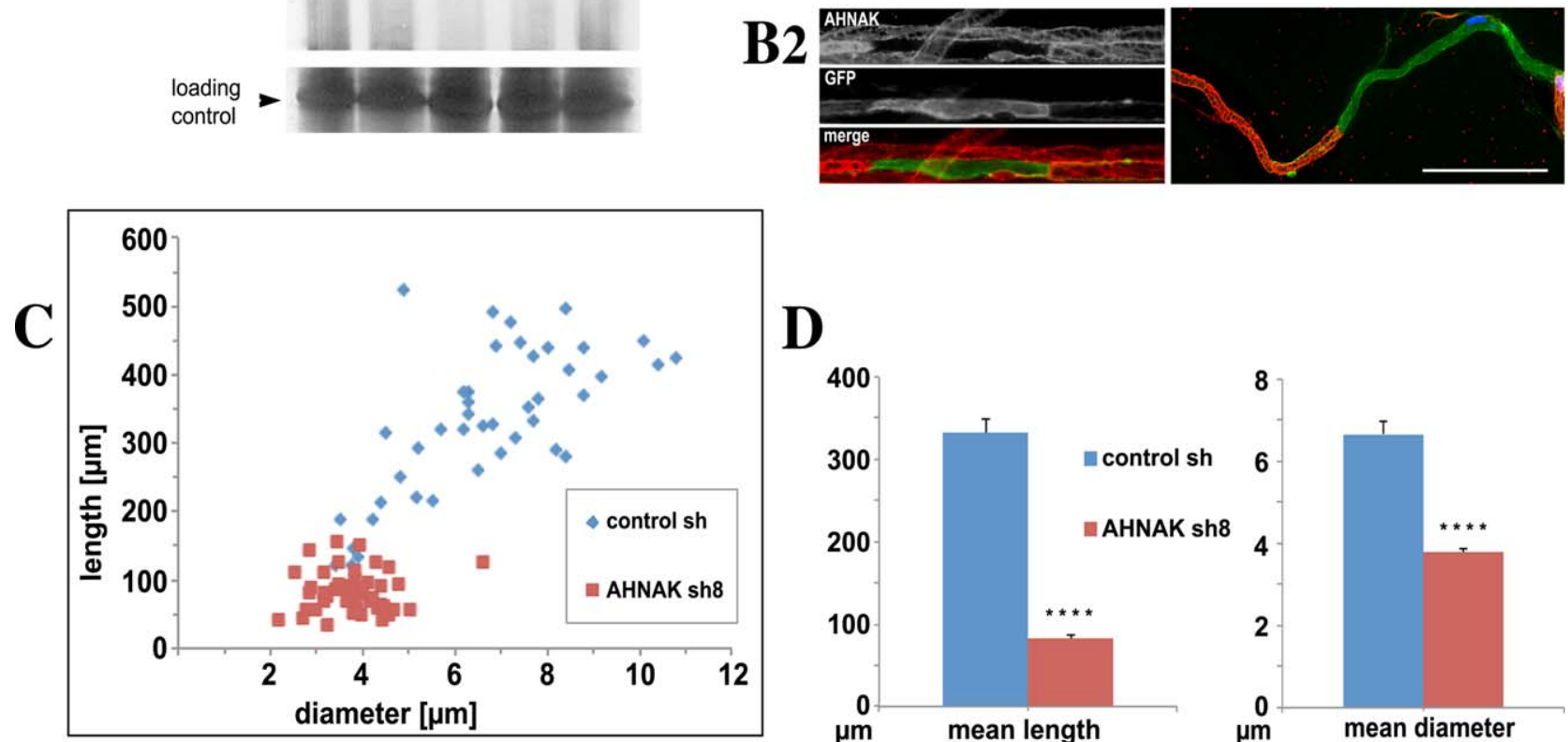

D

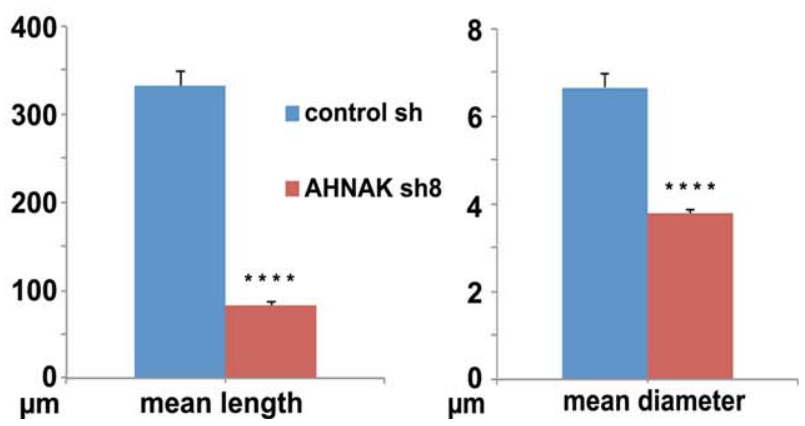

FIGURE 8: In vivo knockdown of ahnak1 in sciatic nerve of newborn mice. (A) Different MISSION (Sigma) shRNA lentiviral constructs were tested on cultured SCs for their capacity to knock down AHNAK expression, assessed here by Western blotting after protein extraction from puromycin-selected cells. Consequently, constructs \#7 and \#8 were chosen for experiments in live animals. (B1) Representative examples of sciatic nerve SCs infected in vivo with lentivirus harboring GFP-tagged shRNA \#8 constructs (top), and control virus (bottom); teased fiber preparation. (B2) Examples of teased fibers from GFP-tagged shRNA \#8 infected nerve, double stained with antibodies against AHNAK1 (red) and GFP (green in merge image), showing effective downregulation of AHNAK1 in the GFP-positive SC. DAPI staining (blue) in the right merge image shows the nucleus of the shRNA \#8-infected SC. Bar, $50 \mu \mathrm{m}$. (C) Graph showing length and diameter of individual GFP-tagged SCs on teased fiber preparations from lentivirus-infected nerve (about 45 cells measured per condition). (D) Statistical evaluation of mean length and mean diameter of control shRNA- versus ahnak1-shRNA \#8-infected SC: knockdown of AHNAK1 leads to about $75 \%$ shorter, and $40 \%$ thinner cells. [Color figure can be viewed in the online issue, which is available at wileyonlinelibrary.com.]

signaling may play a role during oligodendrocyte lineage progression (Relucio et al., 2009).

To assure optimal nerve conductance, myelin segment diameter and extension are controlled by precise regulation of size and organization of baso-lateral (abaxonal) versus apical SC domains (adaxonal membrane, myelin, and SchmidtLanterman incisures), avoiding under- as well as overmyelination (Cotter et al., 2010; Ozcelik et al., 2010). In extension of Sherman and Brophy (2005), Court et al. (2011; see Fig. 8 therein) propose a model for the structural organization of abaxonal compartments: domains characterized by direct apposition of plasma membrane to the myelin sheath contain periaxin, linked by Drp2 to transmembrane $\beta$-dystroglycan $_{43}$ that via $\alpha$-dystroglycan finally binds to basement membrane laminin. In Cajal band domains (and nodal microvilli), F-actin is linked to the plasma membrane via the dystroglycan/dystrophin-116/utrophin complex, but the extracellular part of $\beta$-dystroglycan is cleaved in a finely regulated mechanism by metalloproteinases MMP-2 and -9. The resulting $\beta$-dystroglycan ${ }_{31}$ no longer binds $\alpha$-dystroglycan, which in turn leads to lack of laminin interaction (see also Fig. $4 \mathrm{~A}$, showing relatively high levels of $\beta$-dystroglycan ${ }_{31}$ in sciatic nerve, compared with cultured primary SCs. Note, however, that the relevance of $\beta$-dystroglycan ${ }_{31}$ formation has meanwhile been questioned; Sherman et al., 2012). The ratio between apposed domains and Cajal bands, constant in normal nerve, is correlated with internodal length, and disturbed in muscular dystrophies. Having shown that (i) AHNAK1, which interacts with F-actin (Benaud et al., 2004; Haase et al., 2004), is strongly expressed in Cajal bands, (ii) that siRNA-interference with ahnak1 in SCs affects expression and membrane targeting of the major laminin receptor $\beta$ dystroglycan (Salim et al., 2009), (iii) whose distribution is altered in ahnak1 ${ }^{-1-}$ peripheral nerve, (iv) that coimmunoprecipitates with AHNAK1, and finally, (v) that internodal length in large fibers of ahnak1 ${ }^{-1-}$ peripheral nerve is reduced, a phenomenon even more pronounced after acute knockdown of ahnakl in developing SC in vivo, we 
suggest that AHNAK1 is implicated in the complex cross-talk between the actin cytoskeleton and basement membrane laminin. Our in vitro demonstration that siRNA knockdown of AHNAK1 leads to impaired adhesion to laminin is not contradictory to the model proposed by Court, as the above described domain organization is not found in primary cultured SC. Given the polyionic rod structure of the molecule supposedly spanning up to $1.2 \mu \mathrm{m}$ (Shtivelman et al., 1992; see also Komuro et al., 2004), it even seems possible that AHNAK1 constitutes a physical link between periaxin- and Cajal band domains.

It should be noted that fibers originating from small DRG neurons are themselves expressing AHNAK1 (Salim et al., 2009), and the presence of oversized unmyelinated axons in ahnak1 $1^{-1-}$ sciatic nerve (Fig. 2) might thus be related to AHNAK1 deficiency in SCs and/or axons. However, results of our targeted shRNA knockdown in vivo show that lack of AHNAK1 in SCs suffices to affect the ensheathing process. Moreover, not only myelination, but also Remak bundle formation require basement membrane adhesion of SCs (Yu et al., 2009), and radial sorting of fibers during development is likely to be affected by the altered expression of $\beta$-dystroglycan in ahnak1 ${ }^{-1-}$ SCs (cf., Berti et al., 2011).

The considerably higher stiffness of ahnak1-l- SC processes revealed by our AFM measurements, reflecting a more rigid, less dynamic actin cytoskeleton, correlates well with the observed reduced migration velocity in vitro, and impaired elongation of SCs on axons in vivo. Although to date, the elasticity of SC process in culture seems almost unexplored, we may compare our data with those obtained for neurons, given the resemblance between neurite growth cones and motile tips on SCs, particularly with regard to cytoskeleton composition and organization (see, e.g., Bouquet et al., 2007). Thus, it has long been known that the tension forces implicated in the advance of neurites growing from cultured neurons are essentially generated at the growth cone (Bray, 1979; Lamoureux et al., 1989). In AFM measurements, this is reflected by the higher stiffness of the growth cone, compared with the proximal neurite shaft (Fereol et al., 2011). In fact, strong substrate adhesion along the shaft would rather counteract the traction forces generated at the growth cone, and thus slow down neurite growth (O'Toole et al., 2008). In contrast, a higher than normal stiffness of the ahnak1 $1^{-1-}$ process end tip will inevitably affect its dynamics and motility. The relationship between migration speed and cell-to-substrate adhesion forces is biphasic (Gaussian): intermediate forces are optimal as they allow for both adhesion and release of contacts, while too low forces impede adhesion, too strong forces release of contacts (Cox and Huttenlocher, 1998).

Increased rigidity of SCs lacking AHNAK1 may also have consequences beyond PNS development, as AHNAK1 is thought to contribute to the elastic properties of cell types constantly exposed to physical stress (see, e.g., Gentil et al., 2003; Marg et al., 2010), similar to the function in muscle of titin, another protein of exceptionally high molecular weight (Freiburg et al., 2000). The presence of AHNAK1 could thus be advantageous for peripheral nerve, which in contrast to CNS is not encapsulated in a rigid bone structure.

Interaction between AHNAK1 and the actin cytoskeleton may occur in several ways: (i) via AHNAK1 binding to $\beta$-dystroglycan, itself part of a complex with dystrophin-116/ utrophin, perturbed in ahnak1 $1^{-1-}$ SCs. In SCs, only utrophin associates with F-actin (Court et al., 2009), whereas dystrophin-116 has no actin-binding domain (Byers et al., 1993), in contrast to the high molecular weight isoform from muscle; (ii) via direct binding of AHNAK1-linked $\beta$-dystroglycan to F-actin, as demonstrated for muscle (Chen et al., 2003); (iii) via interaction with the annexin-2/S100A10 complex that in turn regulates the cortical actin cytoskeleton in epithelial cells (Benaud et al., 2004); (iv) in muscle, a naturally occurring AHNAK fragment can by itself stabilize Factin, and induce actin filament bundling in vitro (Haase et al., 2004; Hohaus et al., 2002). Finally, AHNAK1 was shown to be required for the pseudopodial actin dynamics during the epithelial-mesenchymal transition of metastatic cancer cells (Shankar et al., 2010), and the migration of aortic smooth muscle cells in vivo and in vitro (Lim et al., 2013). Thus, absence of AHNAK1 interaction with F-actin (be it direct, or dystroglycan/utrophin-mediated) is a likely explanation for the observed alterations in ahnak1 $1^{-1-}$ SC morphology and motility. The exact mechanism of this interaction, and where exactly AHNAK1 may intervene in the laminindystroglycan complex signaling converging onto the actin cytoskeleton, needs to be further elucidated.

The dystroglycan complex itself has been shown to be indispensable for proper compartmentalization of abaxonal SC domains, thereby influencing myelin stability, sodium channel distribution, and nerve conductance (Saito et al., 2003; Sherman et al., 2012). Dystroglycan-knockout mice exhibit a significant reduction of internodal lengths in peripheral nerve (Court et al., 2009). We demonstrate here that absence of AHNAK1 in myelinating SCs also affects internodal length, most likely due to perturbation of $\beta$-dystroglycan distribution in the abaxonal membrane, albeit to a much lesser degree than complete absence of dystroglycan. In both cases, the reduction of internodal length concerns particularly the larger fibers. Absence of dystroglycan from membrane appositions (that never contain AHNAK1; Salim et al., 2009) will have more dramatic consequences on internodal length than absence of $\beta$-dystroglycan from Cajal bands, which may rather affect their relative extension in comparison to appositions (the relative contributions of appositions and Cajal 
bands in the determination of internodal length are subject of some debate: Court et al., 2011; Sherman et al., 2012). The fact that lack of AHNAK1 does obviously not impede formation of Cajal bands (see Fig. 3) is consistent with the finding that they develop normally also in utrophin-ko mice (as well as in Drp2-ko mice; Sherman et al., 2012).

In view of the rather dramatic effect of the acute abnak1 knockdown on SC elongation on axons (Fig. 8, in comparison to the constitutive ahnak1 knockout, Fig. 7), as well as the significantly higher rigidity, and lower motility of mutant SCs in vitro, it may be asked why the sciatic nerve ultrastructure seems only mildly affected in ahnak1 ${ }^{-1-}$ mice. Moreover, we could not detect any significant differences with wildtype mice in behavioral tests (e.g., toe placement and footprint tests for motor, von Frey-hair stimulation for sensory function; not shown). After all, the absence of a strong phenotype of ahnak1 ${ }^{-1-}$ mouse PNS did not come as a surprise, as these mice behave and reproduce like their wildtype littermates, and a detailed investigation of development and integrity of their epidermis did not reveal any abnormalities (Kouno et al., 2004), despite the well-documented AHNAK1 interaction with cortical F-actin and annexin2/S100A10 in epithelial cells (Benaud et al., 2004). The same is true for $\mathrm{T}$ cells: although AHNAK1 is involved in their calciumdependent activation (Matza et al., 2008), their phenotype in ahnak1 $1^{-1-}$ mice is almost normal. There is good reason to believe that during development (as observed for other knockout mice) expression of a protein with similar properties, probably AHNAK2, compensates for the lack of AHNAK1. Both AHNAK proteins are often co-distributed (Komuro et al., 2004; Marg et al., 2010), both fulfill scaffolding functions, and not least with regard to the structural similarities between AHNAK2 and periaxin (de Morree et al., 2012; Han and Kursula, 2014) it seems likely that AHNAK2 is also implicated in linking the extracellular matrix to the cytoskeleton. This compensatory mechanism is not activated by our acute shRNA knockdown, because development until birth has occurred in presence of AHNAK1.

Although so far no AHNAK1-related pathologies are known, the protein was recently implicated in various diseases ranging from obesity (Kim et al., 2010), to cancer, where its expression level may be a useful marker for potential therapeutic outcome (Chatterjee et al., 2006; Dumitru et al., 2013; Hsu et al., 2013; Leong et al., 2012). In muscle, AHNAK seems involved in dysferlin complex-mediated sarcolemma repair (Dempsey et al., 2012; Kobayashi et al., 2012; Zacharias et al., 2011), and its expression and distribution are secondarily affected in certain myopathies of the limb girdle muscular dystrophy type (Huang et al., 2007, 2008). About $50 \%$ of the hereditary sensorimotor system neuropathies are due to gene mutations related to SCs, or axons (Patzko and von Boxberg et al.: AHNAK1 Function in Schwann Cell Motility

Shy, 2011), at the instar of Charcot-Marie-Tooth-4F neuropathy caused by a mutated periaxin gene (Court et al., 2004, 2009). The data presented here should contribute to the ongoing elucidation of the highly complex, polarized interactions between SCs, axons, and surrounding extracellular matrix required for SC migration, axon ensheathing and myelination during development, but also during the reaction of SCs to pathological situations in the adult.

\section{Acknowledgment}

The authors are indebted to M. Kouno and J. Takeda for their kind authorization to use ahnak1 $1^{-1-}$ mice originally generated in their lab. They wish to thank J. Baudier for generously providing KIS and CQL antibodies to AHNAK, J. Eyer for his valuable advice on electron microscopy of peripheral nerve, M. Garcia for her patience at introducing us into efficient teased fiber preparation, M. Conrath for her advice and implication with tests of sensory functions, and M. Veron for her indefatigable help in preparing the specimen for electron microscopy, even after her retirement. This work was supported by Association Française contre les Myopathies (AFM, to Y.v.B and F.N.). The authors declare no competing financial interests.

\section{References}

Adlkofer K, Martini R, Aguzzi A, Zielasek J, Toyka KV, Suter U. 1995. Hypermyelination and demyelinating peripheral neuropathy in Pmp22-deficient mice. Nat Genet 11:274-280.

Benaud C, Gentil BJ, Assard N, Court M, Garin J, Delphin C, Baudier J. 2004. AHNAK interaction with the annexin 2/S100A10 complex regulates cell membrane cytoarchitecture. J Cell Biol 164:133-144.

Berti C, Bartesaghi L, Ghidinelli M, Zambroni D, Figlia G, Chen ZL, Quattrini A, Wrabetz L, Feltri ML. 2011. Non-redundant function of dystroglycan and beta1 integrins in radial sorting of axons. Development 138:4025-4037.

Bouquet C, Ravaille-Veron M, Propst F, Nothias F. 2007. MAP1B coordinates microtubule and actin filament remodeling in adult mouse Schwann cell tips and DRG neuron growth cones. Mol Cell Neurosci 36:235-247.

Boxberg YV. 1988. Protein analysis on two-dimensional polyacrylamide gels in the femtogram range: Use of a new sulfur-labeling reagent. Anal Biochem 169:372-375.

Bray D. 1979. Mechanical tension produced by nerve cells in tissue culture. J Cell Sci 37:391-410.

Bunge RP, Bunge MB. 1978. Evidence that contact with connective tissue matrix is required for normal interaction between Schwann cells and nerve fibers. J Cell Biol 78:943-950.

Byers TJ, Lidov HG, Kunkel LM. 1993. An alternative dystrophin transcript specific to peripheral nerve. Nat Genet 4:77-81.

Canadas P, Laurent VM, Oddou C, Isabey D, Wendling S. 2002. A cellular tensegrity model to analyse the structural viscoelasticity of the cytoskeleton. $\mathrm{J}$ Theor Biol 218:155-173.

Chatterjee M, Mohapatra S, Ionan A, Bawa G, Ali-Fehmi R, Wang X, Nowak J, Ye B, Nahhas FA, Lu K, Witkin SS, Fishman D, Munkarah A, Morris R, Levin NK, Shirley NN, Tromp G, Abrams J, Draghici S, Tainsky MA. 2006. Diagnostic markers of ovarian cancer by high-throughput antigen cloning and detection on arrays. Cancer Res 66:1181-1190. 
Chen YJ, Spence HJ, Cameron JM, Jess T, Ilsley JL, Winder SJ. 2003. Direct interaction of beta-dystroglycan with F-actin. Biochem J 375:329-337.

Colognato H, ffrench-Constant C, Feltri ML. 2005. Human diseases reveal novel roles for neural laminins. Trends Neurosci 28:480-486.

Cornbrooks CJ, Carey DJ, McDonald JA, Timpl R, Bunge RP. 1983. In vivo and in vitro observations on laminin production by Schwann cells. Proc Natl Acad Sci USA 80:3850-3854.

Cotter L, Ozcelik M, Jacob C, Pereira JA, Locher V, Baumann R, Relvas JB, Suter U, Tricaud N. 2010. Dlg1-PTEN interaction regulates myelin thickness to prevent damaging peripheral nerve overmyelination. Science 328:14151418.

Court FA, Hewitt JE, Davies K, Patton BL, Uncini A, Wrabetz L, Feltri ML. 2009. A laminin-2, dystroglycan, utrophin axis is required for compartmentalization and elongation of myelin segments. J Neurosci 29:3908-3919.

Court FA, Sherman DL, Pratt T, Garry EM, Ribchester RR, Cottrell DF, Fleetwood-Walker SM, Brophy PJ. 2004. Restricted growth of Schwann cells lacking Cajal bands slows conduction in myelinated nerves. Nature 431:191195.

Court FA, Zambroni D, Pavoni E, Colombelli C, Baragli C, Figlia G, Sorokin L, Ching W, Salzer JL, Wrabetz L, Feltri ML. 2011. MMP2-9 cleavage of dystroglycan alters the size and molecular composition of schwann cell domains. J Neurosci 31:12208-12217.

Cox EA, Huttenlocher A. 1998. Regulation of integrin-mediated adhesion during cell migration. Microsc Res Tech 43:412-419.

de Morree A, Droog M, Grand Moursel L, Bisschop IJ, Impagliazzo A, Frants RR, Klooster R, van der Maarel SM. 2012. Self-regulated alternative splicing at the AHNAK locus. FASEB J 26:93-103.

Dempsey BR, Rezvanpour A, Lee TW, Barber KR, Junop MS, Shaw GS. 2012. Structure of an asymmetric ternary protein complex provides insight for membrane interaction. Structure 20:1737-1745.

Dumitru CA, Bankfalvi A, Gu X, Zeidler R, Brandau S, Lang S. 2013. AHNAK and inflammatory markers predict poor survival in laryngeal carcinoma. PLoS One 8:e56420.

Feltri ML, Wrabetz L. 2005. Laminins and their receptors in Schwann cells and hereditary neuropathies. J Peripher Nerv Syst 10:128-143.

Fereol S, Fodil R, Barnat M, Georget V, Milbreta U, Nothias F. 2011. Micropatterned ECM substrates reveal complementary contribution of low and high affinity ligands to neurite outgrowth. Cytoskeleton (Hoboken) 68:373388.

Fereol S, Fodil R, Laurent VM, Balland M, Louis B, Pelle G, Henon S, Planus E, Isabey D. 2009. Prestress and adhesion site dynamics control cell sensitivity to extracellular stiffness. Biophys J 96:2009-2022.

Freiburg A, Trombitas K, Hell W, Cazorla O, Fougerousse F, Centner T, Kolmerer B, Witt C, Beckmann JS, Gregorio CC, Granzier H, Labeit S. 2000. Series of exon-skipping events in the elastic spring region of titin as the structural basis for myofibrillar elastic diversity. Circ Res 86:11141121.

Gentil BJ, Delphin C, Benaud C, Baudier J. 2003. Expression of the giant protein AHNAK (desmoyokin) in muscle and lining epithelial cells. J Histochem Cytochem 51:339-348.

Gillespie CS, Sherman DL, Blair GE, Brophy PJ. 1994. Periaxin, a novel protein of myelinating Schwann cells with a possible role in axonal ensheathment. Neuron 12:497-508.

Goebbels S, Oltrogge JH, Wolfer S, Wieser GL, Nientiedt T, Pieper A, Ruhwedel T, Groszer M, Sereda MW, Nave KA. 2012. Genetic disruption of Pten in a novel mouse model of tomaculous neuropathy. EMBO Mol Med 4: 486-499.

Haase H, Alvarez JP, D, Doller A, Behlke J, Erdmann J, Hetzer R, RegitzZagrosek V, Vassort G, Morano I. 2005. Ahnak is critical for cardiac Ca(V)1.2 calcium channel function and its beta-adrenergic regulation. FASEB J 19: 1969-1977.
Haase H, Pagel I, Khalina Y, Zacharzowsky U, Person V, Lutsch G, Petzhold D, Kott M, Schaper J, Mlorano. 2004. The carboxyl-terminal ahnak domain induces actin bundling and stabilizes muscle contraction. FASEB J 18:839841.

Han H, Kursula P. 2014. Periaxin and AHNAK nucleoprotein 2 form intertwined homodimers through domain swapping. J Biol Chem. 2014, Mar 27 in press. doi: 10.1074/jbc.M114.554816.

Helbling-Leclerc A, Zhang X, Topaloglu H, Cruaud C, Tesson F, Weissenbach J, Tome FM, Schwartz K, Fardeau M, Tryggvason K, Guicheney P. 1995. Mutations in the laminin alpha 2-chain gene (LAMA2) cause merosin-deficient congenital muscular dystrophy. Nat Genet 11:216-218.

Hohaus A, Person V, Behlke J, Schaper J, Morano I, Haase H. 2002. The carboxyl-terminal region of ahnak provides a link between cardiac L-type $\mathrm{Ca} 2+$ channels and the actin-based cytoskeleton. FASEB J 16:1205-1216.

Hsu YC, Chen HY, Yuan S, Yu SL, Lin CH, Wu G, Yang PC, Li KC. 2013. Genome-wide analysis of three-way interplay among gene expression, cancer cell invasion and anti-cancer compound sensitivity. BMC Med 11:106.

Huang $Y$, de Morree A, van Remoortere A, Bushby K, Frants RR, Dunnen JT, van der Maarel SM. 2008. Calpain 3 is a modulator of the dysferlin protein complex in skeletal muscle. Hum Mol Genet 17:1855-1866.

Huang Y, Laval SH, van Remoortere A, Baudier J, Benaud C, Anderson LV, Straub V, Deelder A, Frants RR, den Dunnen JT, Bushby K, van der Maarel SM. 2007. AHNAK, a novel component of the dysferlin protein complex, redistributes to the cytoplasm with dysferlin during skeletal muscle regeneration. FASEB J 21:732-742.

James M, Nuttall A, Ilsley JL, Ottersbach K, Tinsley JM, Sudol M, Winder SJ. 2000. Adhesion-dependent tyrosine phosphorylation of (beta)-dystroglycan regulates its interaction with utrophin. J Cell Sci 113:1717-1726.

Kim IY, Jung J, Jang M, Ahn YG, Shin JH, Choi JW, Sohn MR, Shin SM, Kang DG, Lee HS, Bae YS, Ryu do H, Seong JK, Hwang GS. 2010. 1H NMR-based metabolomic study on resistance to diet-induced obesity in AHNAK knockout mice. Biochem Biophys Res Commun 403:428-434.

Kobayashi K, Izawa T, Kuwamura M, Yamate J. 2012. Dysferlin and anima models for dysferlinopathy. J Toxicol Pathol 25:135-147.

Komuro A, Masuda Y, Kobayashi K, Babbitt R, Gunel M, Flavell RA, Marchesi VT. 2004. The AHNAKs are a class of giant propeller-like proteins that associate with calcium channel proteins of cardiomyocytes and other cells. Proc Natl Acad Sci USA 101:4053-4058.

Kouno M, Kondoh G, Horie K, Komazawa N, Ishii N, Takahashi Y, Takeda J, Hashimoto T. 2004. Ahnak/Desmoyokin is dispensable for proliferation, differentiation, and maintenance of integrity in mouse epidermis. J Invest Dermatol 123:700-707.

Lamoureux P, Buxbaum RE, Heidemann SR. 1989. Direct evidence that growth cones pull. Nature 340:159-162.

Laurent VM, Henon S, Planus E, Fodil R, Balland M, Isabey D, Gallet F. 2002 Assessment of mechanical properties of adherent living cells by bead micromanipulation: Comparison of magnetic twisting cytometry vs optical tweezers. J Biomech Eng 124:408-421.

Lee SM, Sha D, Mohammed AA, Asress S, Glass JD, Chin LS, Li L. 2013. Motor and sensory neuropathy due to myelin infolding and paranodal damage in a transgenic mouse model of Charcot-Marie-Tooth disease type 1C. Hum Mol Genet 22:1755-1770.

Leong S, Nunez AC, Lin MZ, Crossett B, Christopherson RI, Baxter RC. 2012 iTRAQ-based proteomic profiling of breast cancer cell response to doxorubicin and TRAIL. J Proteome Res 11:3561-3572.

Lim HJ, Kang DH, Lim JM, Kang DM, Seong JK, Kang SW, Bae YS. 2013. Function of Ahnak protein in aortic smooth muscle cell migration through Rac activation. Cardiovasc Res 97:302-310.

Marg A, Haase H, Neumann T, Kouno M, Morano I. 2010. AHNAK1 and AHNAK2 are costameric proteins: AHNAK1 affects transverse skeletal muscle fiber stiffness. Biochem Biophys Res Commun 401:143-148.

Matza D, Badou A, Jha MK, Willinger T, Antov A, Sanjabi S, Kobayashi KS, Marchesi VT, Flavell RA. 2009. Requirement for AHNAK1-mediated calcium 
signaling during T lymphocyte cytolysis. Proc Natl Acad Sci USA 106:97859790

Matza D, Badou A, Kobayashi KS, Goldsmith-Pestana K, Masuda Y, Komuro A, McMahon-Pratt D, Marchesi VT, Flavell RA. 2008. A scaffold protein, AHNAK1, is required for calcium signaling during $T$ cell activation. Immunity 28:64-74.

McKee KK, Yang DH, Patel R, Chen ZL, Strickland S, Takagi J, Sekiguchi K, Yurchenco PD. 2012. Schwann cell myelination requires integration of laminin activities. J Cell Sci 125:4609-4619.

Meintanis S, Thomaidou D, Jessen KR, Mirsky R, Matsas R. 2001. The neuronglia signal beta-neuregulin promotes Schwann cell motility via the MAPK pathway. Glia 34:39-51.

O'Toole M, Lamoureux P, Miller KE. 2008. A physical model of axonal elongation: Force, viscosity, and adhesions govern the mode of outgrowth. Biophys J 94:2610-2620.

Ozcelik M, Cotter L, Jacob C, Pereira JA, Relvas JB, Suter U, Tricaud N. 2010. Pals1 is a major regulator of the epithelial-like polarization and the extension of the myelin sheath in peripheral nerves. J Neurosci 30:41204131.

Pankonien I, Otto A, Dascal N, Morano I, Haase H. 2012. Ahnak1 interaction is affected by phosphorylation of Ser-296 on Cavbeta(2). Biochem Biophys Res Commun 421:184-189.

Patzko A, Shy ME. 2011. Update on Charcot-Marie-tooth disease. Curr Neurol Neurosci Rep 11:78-88.

Relucio J, Tzvetanova ID, Ao W, Lindquist S, Colognato H. 2009. Laminin alters fyn regulatory mechanisms and promotes oligodendrocyte development. J Neurosci 29:11794-11806.

Royuela M, Chazalette D, Hugon G, Paniagua R, Guerlavais V, Fehrentz JA, Martinez J, Labbe JP, Rivier F, Mornet D. 2003. Formation of multiple complexes between beta-dystroglycan and dystrophin family products. J Muscle Res Cell Motil S 24:387-397.

Saito F, Moore SA, Barresi R, Henry MD, Messing A, Ross-Barta SE, Cohn RD, Williamson RA, Sluka KA, Sherman DL, Brophy PJ, Schmelzer JD, Low PA, Wrabetz L, Feltri ML, Campbell KP. 2003. Unique role of dystroglycan in peripheral nerve myelination, nodal structure, and sodium channel stabilization. Neuron S 38:747-758.

Salim C, Boxberg YV, Alterio J, Fereol S, Nothias F. 2009. The giant protein AHNAK involved in morphogenesis and laminin substrate adhesion of myelinating Schwann cells. Glia 57:535-549. von Boxberg et al.: AHNAK1 Function in Schwann Cell Motility

Shankar J, Messenberg A, Chan J, Underhill TM, Foster LJ, Nabi IR. 2010 Pseudopodial actin dynamics control epithelial-mesenchymal transition in metastatic cancer cells. Cancer Res 70:3780-3790.

Sherman DL, Brophy PJ. 2005. Mechanisms of axon ensheathment and myelin growth. Nat Rev Neurosci 6:683-690.

Sherman DL, Wu LM, Grove M, Gillespie CS, Brophy PJ. 2012. Drp2 and periaxin form Cajal bands with dystroglycan but have distinct roles in Schwann cell growth. J Neurosci 32:9419-9428.

Shtivelman E, Cohen FE, Bishop JM. 1992. A human gene (AHNAK) encoding an unusually large protein with a 1.2-microns polyionic rod structure. Proc Natl Acad Sci USA 89:5472-5476.

Sotgia F, Bonuccelli G, Bedford M, Brancaccio A, Mayer U, Wilson MT, Campos-Gonzalez R, Brooks JW, Sudol M, Lisanti MP. 2003. Localization of phospho-beta-dystroglycan (pY892) to an intracellular vesicular compartment in cultured cells and skeletal muscle fibers in vivo. Biochemistry 42:7110 7123.

Sunada Y, Bernier SM, Kozak CA, Yamada Y, Campbell KP. 1994. Deficiency of merosin in dystrophic dy mice and genetic linkage of laminin $M$ chain gene to dy locus. J Biol Chem 269:13729-13732.

Taveggia C, Zanazzi G, Petrylak A, Yano H, Rosenbluth J, Einheber S, Xu X Esper RM, Loeb JA, Shrager P, Chao MV, Falls DL, Role L, Salzer JL. 2005. Neuregulin-1 type III determines the ensheathment fate of axons. Neuron 47: 681-694.

von Boxberg Y, Salim C, Soares S, Baloui H, Alterio J, Ravaille-Veron M, Nothias F. 2006. Spinal cord injury-induced up-regulation of AHNAK, expressed in cells delineating cystic cavities, and associated with neoangiogenesis. Eur J Neurosci 24:1031-1041.

Wang N, Tolic-Norrelykke IM, Chen J, Mijailovich SM, Butler JP, Fredberg JJ, Stamenovic D. 2002. Cell prestress. I. Stiffness and prestress are closely associated in adherent contractile cells. Am J Physiol Cell Physiol 282:C606-616.

Wendling S, Oddou C, Isabey D. 1999. Stiffening response of a cellular tensegrity model. J Theor Biol 196:309-325.

Yu WM, Yu H, Chen ZL, Strickland S. 2009. Disruption of laminin in the peripheral nervous system impedes nonmyelinating Schwann cell development and impairs nociceptive sensory function. Glia 57:850-859.

Zacharias U, Purfurst B, Schowel V, Morano I, Spuler S, Haase H. 2011. Ahnak1 abnormally localizes in muscular dystrophies and contributes to muscle vesicle release. J Muscle Res Cell Motil 32:271-280. 